\title{
Marine Heatwave, Harmful Algae Blooms and an Extensive Fish Kill Event During 2013 in South Australia
}

\section{OPEN ACCESS}

Edited by:

Neill Andrew Herbert, The University of Auckland,

New Zealand

Reviewed by:

Mikko Juhani Nikinmaa, University of Turku, Finland

Pedro Miguel Guerreiro, University of Algarve, Portugal

*Correspondence: Shane D. Roberts shane.roberts@sa.gov.au

Specialty section: This article was submitted to

Aquatic Physiology,

a section of the journal Frontiers in Marine Science

Received: 02 July 2019 Accepted: 17 September 2019 Published: 09 October 2019

Citation:

Roberts SD, Van Ruth $P D$, Wilkinson C, Bastianello SS and

Bansemer MS (2019) Marine Heatwave, Harmful Algae Blooms and an Extensive Fish Kill Event During 2013 in South Australia.

Front. Mar. Sci. 6:610. doi: 10.3389/fmars.2019.00610

\section{Shane D. Roberts ${ }^{1 *}$, Paul D. Van Ruth ${ }^{2}$, Clinton Wilkinson ${ }^{3}$, Stella S. Bastianello ${ }^{4}$ and Matthew S. Bansemer ${ }^{1}$}

${ }^{1}$ Primary Industries and Regions South Australia (SA), Fisheries and Aquaculture, Adelaide, SA, Australia, ${ }^{2}$ South Australian Research and Development Institute, Aquatic Sciences, Henley Beach, SA, Australia, ${ }^{3}$ Primary Industries and Regions SA, Biosecurity SA, Adelaide, SA, Australia, ${ }^{4}$ Gribbles Veterinary Pathology, VETLAB, Glenside, SA, Australia

In 2013, South Australia experienced unusually high and variable water temperatures $\left(5^{\circ} \mathrm{C}\right.$ above the historic average), with a peak sea surface temperature of approximately $27^{\circ} \mathrm{C}$ over a wide geographic area covering both gulfs and shelf waters. Over the same period and similar geographic area, a prolonged and widespread marine mortality event occurred. From January to May 2013, low level rates of incidental morbidity and mortality of abalone (Haliotis rubra and H. laevigata) and at least 29 fish species were observed. Mortalities were geographically extensive from Port MacDonnell on the South Coast of South Australia to Point Drummond on Eyre Peninsula, and including two gulf systems, spanning approximately 2,900 km of coastline. Mortalities were investigated using gross pathology, histopathology, bacterial culture and polymerase chain reaction (PCR) techniques. Water samples were collected to assess water column nutrient status and phytoplankton biomass levels and community composition. High nutrient concentrations were suggestive of high phytoplankton productivity, with conditions conducive to diatom blooms. A harmful (abrasive) diatom, Chaetoceros coarctatus, was observed in higher concentrations than the historical average. Observed fish mortalities were restricted to a small proportion of the populations and primarily comprised of temperate small-bodied benthic inshore species. Fish histopathology was suggestive of prolonged stress (melanomacrophage aggregation in spleens and kidneys), physical gill damage (focal gill lesions likely caused by $C$. coarctatus) and lethal bacterial septicaemia. Infectious and notifiable diseases were ruled out in all fish and abalone samples. Abalone mortalities were also restricted to a small proportion of the population with thermal stress a likely contributing factor that resulted in terminal secondary bacterial infections. A marine heatwave event, which promoted blooms of algae, including C. coarctatus, was likely the primary cause of widespread marine mortalities throughout South Australia in 2013. With marine heatwaves projected to increase in frequency, duration and spatial extent, this investigation demonstrated that most at risk will be temperate species in shallow water habitats already at their upper thermal tolerance limits, particularly those with high site fidelity. This should be considered in future climate proofing strategies, including risk and impact assessments underpinning the management of marine resources, fisheries, aquaculture and ecotourism.

Keywords: marine mortality, abalone, histopathology, marine heatwave, climate change, harmful algae, phytoplankton, Chaetoceros coarctatus 


\section{INTRODUCTION}

Fish kills are a global phenomenon and can be attributed to a number of natural oceanographic cycles, disease outbreaks, harmful algae blooms (HAB), flooding events, water quality (e.g., hypoxia and temperature extremes) and pollution (Brusle, 1995; Hobday et al., 2008; Kim and Oda, 2010; Rodger et al., 2010; McCarthy et al., 2014). Climate change has been suggested to exacerbate some of these factors, including marine diseases, stressed and modified marine ecosystems, marine heatwaves and algae blooms, which lead to greater and more widespread fish kills (Harvell et al., 1999, 2002; Pittock(ed.), 2003; Hobday et al., 2008; Frölicher et al., 2018).

While small scale fish kills can be seasonally frequent natural events, large scale extensive fish kills can seem apocalyptic to the general public, fuelling media and public concern, particularly when the cause cannot be immediately determined. That was the case during this 2013 fish kill investigation, which fuelled an array of presumed causes by media and the public. The term "apocalypse" is derived from the Greek word Apokalypsis, meaning "lifting of the veil" or "uncovering." The ultimate challenge for fish kill investigations is uncovering the cause, which often remains unknown (Lugg, 2000; La and Cooke, 2011). The timely collection and appropriate preservation of both aquatic animals and water samples prior to deterioration can be problematic (Harvell et al., 1999; La and Cooke, 2011). Investigations often rely on anecdotal evidence and climatic weather observations as the basis for attributing "likely causes."

Australia has well established national fish kill investigation and emergency response frameworks (Nowak et al., 2005; AGDAFF, 2007; Roberts et al., 2013). In Australia, a fish kill is defined as a significant and sudden mortality of wild aquatic animals (non-mammalian) (AG-DAFF, 2007), although some jurisdictions also include mass mortality in cultured fish (Lugg, 2000). Australia's national guidelines include suggested trigger values for when to investigate fish kills, which are five affected or dead fish $>100 \mathrm{~mm}$, or $20 \mathrm{fish}<100 \mathrm{~mm}$. Fish kills are generally investigated by the government to rule out aquatic disease outbreaks, human health risks and environmental harm (e.g., chemical, oil spills). Early detection of these factors is important to ensure timely and effective response aimed at minimizing ecological harm, and impacts on fisheries and aquaculture sectors and supporting seafood export markets particularly with regard to ruling out notifiable diseases that can impact trade.

Few large scale fish kills have occurred in the last two decades in South Australia. These larger scale fish kills were typically caused by harmful algae blooms (Roberts et al., 2014) or significant disease outbreaks such as Pilchard herpesvirus (PHV) in Sardines (Sardinops sagax neopilchardus; Gaughan et al., 2000; Gaut, 2001), Perkinsus olseni in abalone (Goggin and Lester, 1995), and ostreid herpesvirus-1 microvariant (OsHV-1 $\mu$ var) in feral Pacific oyster populations in the Port Adelaide River estuary system in 2018.

In South Australia, Spencer Gulf and Gulf St Vincent are inverse estuary gulf systems and are considered "seasonally subtropical systems" (Rogers et al., 2003; Shepherd and Baker, 2014). In summer, the average water temperature at the entrance of these gulfs is approximately $21^{\circ} \mathrm{C}$, reaching an average of $24.5^{\circ} \mathrm{C}$ at the top of Spencer Gulf, peaking at up to $28^{\circ} \mathrm{C}$ over short periods (Roberts et al., 2012; Shepherd and Baker, 2014). The coastal inshore waters of South Australia are home to both temperate, sub-tropical and tropical marine species (Shepherd, 1984; Edyvane and Shepherd, 1999; Rogers et al., 2003; Roberts et al., 2012). While tropical species are well suited to the warm summer water temperatures in South Australia's shallow gulf waters (Roberts et al., 2012), some temperate marine species may be at their physiological tolerance limits. These thermal tolerance limits may be exceeded during marine heatwave events leading to marine mortalities (Pearce and Feng, 2013; Frölicher et al., 2018).

Marine heatwaves can have devastating impacts on ecosystems and commercially important species (Frölicher et al., 2018). Extreme water temperatures and subsequent harmful algae blooms cause numerous fish kills worldwide (Brusle, 1995; Rodger et al., 2010; Pearce and Feng, 2013). During summer and autumn of 2013, South Australia experienced unusually high and variable water temperatures $\left(5^{\circ} \mathrm{C}\right.$ above the historic average), with a peak SST of approximately $27^{\circ} \mathrm{C}$ over a wide geographic area covering both gulfs and shelf waters. During this period, and across a similar geographic area, South Australia experienced an ongoing and widespread fish kill event that peaked during March and April 2013. Large numbers of dead fish in Spencer Gulf were initially reported on 25 January, and over the next 2 months dead fish washed ashore across the State. This event coincided with other unusual observations including dolphin mortalities, which were associated with an outbreak of morbillivirus (Kemper et al., 2016). Further, large amounts of dead seagrass/macro-algae and animal species observed outside their normal range (e.g., marine turtle species). This paper provides an overview of this large scale fish kill investigation, which included fish and abalone diagnostics, water nutrient profiles, phytoplankton abundance and community composition, and climatic observations.

\section{MATERIALS AND METHODS}

\section{Sites}

Fish and abalone morbidity and mortality were reported by members of the public and government staff across the South Australian coastline from January to May 2013 (Figure 1 and Table 1). Reporting is documented as number of reports for each day and site. The extent of mortalities covered approximately 2,900 km of coastline from Port MacDonnell in South Australia's south-east to Point Drummond on the Eyre Peninsula, including two large gulf systems; Spencer Gulf and Gulf St Vincent (Figure 1). The large majority of reports were verified through site visits, photographic evidence and/or a detailed report was provided from a reputable source (e.g., government personnel or dive club). Regional based government staff conducted site visits at a number of locations during the investigation, which were up to $\sim 700 \mathrm{~km}$ from Adelaide (capital city of South Australia). During site visits, estimates of mortality and environmental conditions were recorded, samples of water, fish and/or abalone were collected and photographs were taken in some instances. Given the ongoing nature of the event, and public concern, it 


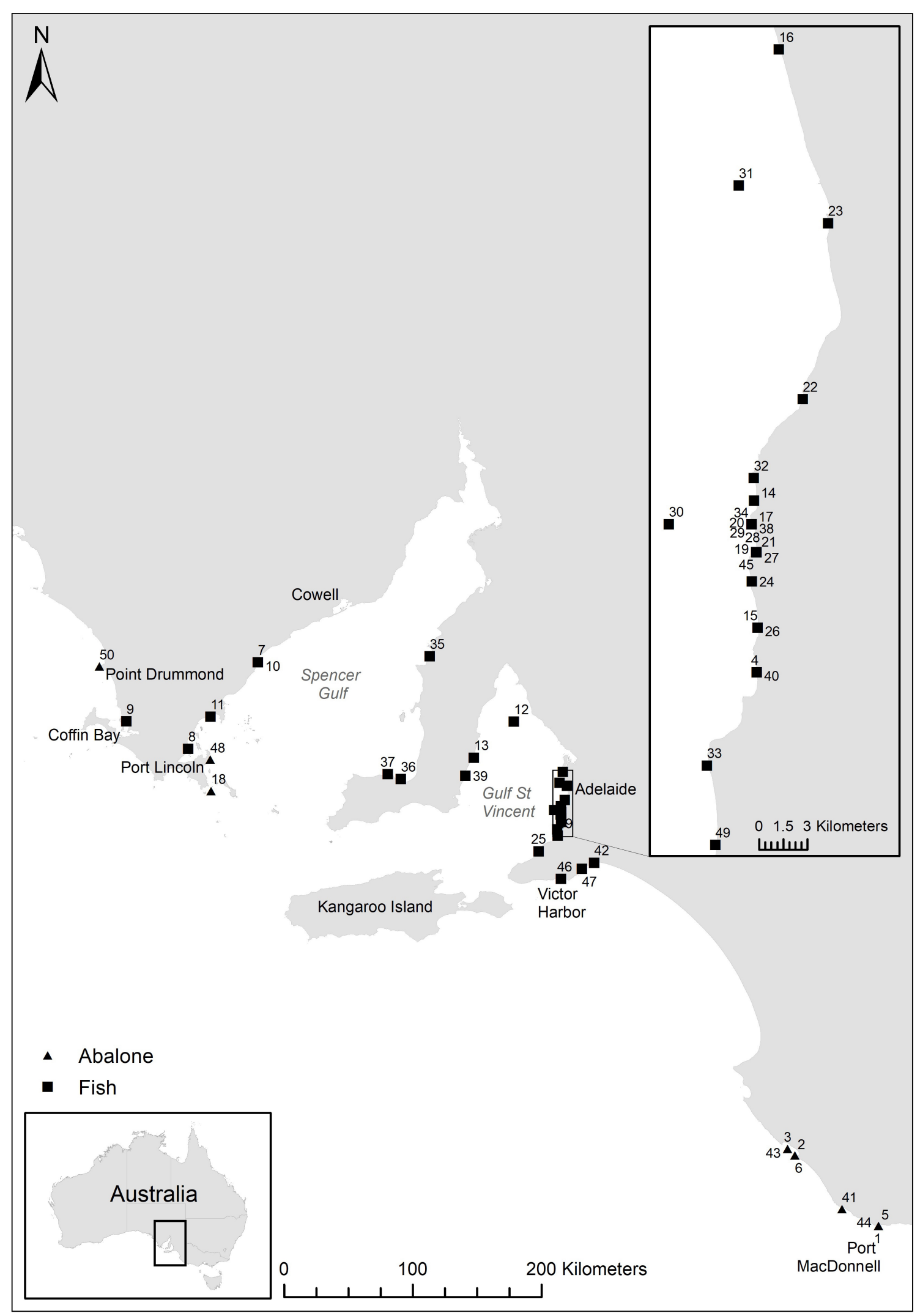

FIGURE 1 | Reported fish kill (fish and abalone) locations across South Australia. Numbers refer to fish kill events in Table 1. 
TABLE 1 | Number, date and locations of reported fish and abalone kills.

\begin{tabular}{|c|c|c|c|}
\hline Number & Date reported & Fish Kill - Locations & Fish/Abalone \\
\hline 1 & $11 / 01 / 2013$ & Port Macdonell & Abalone \\
\hline 2 & $11 / 01 / 2013$ & Beachport - SouthEnd & Abalone \\
\hline 3 & $17 / 01 / 2013$ & Ringwood reef & Abalone \\
\hline 4 & $25 / 01 / 2013$ & Maslin Beach & Fish \\
\hline 5 & $19 / 02 / 2013$ & Port Macdonell & Abalone \\
\hline 6 & $19 / 02 / 2013$ & Beachport - SouthEnd & Abalone \\
\hline 7 & $1 / 03 / 2013$ & Port Neil & Fish \\
\hline 8 & $3 / 03 / 2013$ & Port Lincoln & Fish \\
\hline 9 & 10/03/2013 & Dutton Bay & Fish \\
\hline 10 & $15 / 03 / 2013$ & Port Neil & Fish \\
\hline 11 & $17 / 03 / 2013$ & Moonlight Bay & Fish \\
\hline 12 & $17 / 03 / 2013$ & $23 \mathrm{~km}$ west of West lakes & Fish \\
\hline 13 & 18/03/2013 & Port Vincent & Fish \\
\hline 14 & $21 / 03 / 2013$ & Christies Beach & Fish \\
\hline 15 & 22/03/2013 & Moana & Fish \\
\hline 16 & $25 / 03 / 2013$ & Tennyson & Fish \\
\hline 17 & 25/03/2013 & Port Noarlunga & Fish \\
\hline 18 & 25/03/2013 & Port Lincoln - Thorny Passage & Abalone \\
\hline 19 & 26/03/2013 & Port Noarlunga & Fish \\
\hline 20 & 27/03/2013 & Port Noarlunga & Fish \\
\hline 21 & 28/03/2013 & Port Noarlunga & Fish \\
\hline 22 & 28/03/2013 & Hallett Cove & Fish \\
\hline 23 & 29/03/2013 & Glenelg & Fish \\
\hline 24 & 29/03/2013 & Seaford & Fish \\
\hline 25 & $30 / 03 / 2013$ & Normanville - North Beach & Fish \\
\hline 26 & $31 / 03 / 2013$ & Moana & Fish \\
\hline 27 & $31 / 03 / 2013$ & Onkaparinga river mouth & Fish \\
\hline 28 & $31 / 03 / 2013$ & Port Noarlunga & Fish \\
\hline 29 & $1 / 04 / 2013$ & Port Noarlunga & Fish \\
\hline 30 & $3 / 04 / 2013$ & $4 \mathrm{~km}$ west of Port Noarlunga & Fish \\
\hline 31 & $3 / 04 / 2013$ & $4 \mathrm{~km}$ west of West Beach & Fish \\
\hline 32 & $3 / 04 / 2013$ & O'Sullivans Beach & Fish \\
\hline 33 & $3 / 04 / 2013$ & Aldinga & Fish \\
\hline 34 & $4 / 04 / 2013$ & Port Noarlunga & Fish \\
\hline 35 & $6 / 04 / 2013$ & Port Hughes & Fish \\
\hline 36 & 7/04/2013 & Point Turton & Fish \\
\hline 37 & $7 / 04 / 2013$ & Point Souttar & Fish \\
\hline 38 & 7/04/2013 & Port Noarlunga & Fish \\
\hline 39 & 8/04/2013 & Stansbury & Fish \\
\hline 40 & 8/04/2013 & Maslin Beach & Fish \\
\hline 41 & 8/04/2013 & Gerloff Bay & Abalone \\
\hline 42 & $10 / 04 / 2013$ & Basham Beach & Fish \\
\hline 43 & $10 / 04 / 2013$ & Ringwood reef & Abalone \\
\hline 44 & $10 / 04 / 2013$ & Port Macdonell & Abalone \\
\hline 45 & $17 / 04 / 2013$ & Onkaparinga river mouth & Fish \\
\hline 46 & $17 / 04 / 2013$ & Waitpinga & Fish \\
\hline 47 & 20/04/2013 & Victor Harbor & Fish \\
\hline 48 & $22 / 04 / 2013$ & McLaren Point & Abalone \\
\hline 49 & $24 / 04 / 2013$ & Sellicks Beach & Fish \\
\hline 50 & $4 / 05 / 2013$ & Point Drummond & Abalone \\
\hline
\end{tabular}

became important to collect fresh samples useful for analyses. Boat and dive surveys were conducted at a number of sites across South Australia to collect moribund or fresh dead fish, abalone, water and phytoplankton samples. Dive surveys were conducted at three sites along the Adelaide Metropolitan coast where fish kills had been reported (Port Noarlunga, Hallett Cove, and Glenelg) to investigate live fish populations with underwater video recording.

\section{Water Analysis Sample Collection}

Water was sampled at the $10 \mathrm{~m}$ depth contour at each station (see Table 2). Triplicate water samples were collected from 1 to $2 \mathrm{~m}$ depth. Samples were kept cool, in the dark, and returned to the laboratory within $3 \mathrm{~h}$.

\section{Nutrients}

A $100 \mathrm{ml}$ aliquot of each replicate sample was filtered through a $0.45 \mu \mathrm{m}$ filter for macro-nutrient analysis in the environmental chemistry laboratory at South Australian Research and Development Institute (SARDI), South Australian Aquatic Science Centre (SAASC; West Beach, South Australia). Dissolved ammonium ( $\mathrm{NH}_{3}$, APHA-AWWA-WPCF 1998a, detection limit $0.071 \mu \mathrm{M})$, oxides of nitrogen $\left(\mathrm{NO}_{x}\right.$, APHAAWWA-WPCF 1998b, detection limit $0.071 \mu \mathrm{M}$ ), phosphate $\left(\mathrm{PO}_{4}\right.$, APHA -AWWA WPCF 1998c, detection limit $\left.0.032 \mu \mathrm{M}\right)$ and silicate $\left(\mathrm{SiO}_{2}\right.$, APHA-AWWA-WPCF 1998d, detection limit $0.333 \mu \mathrm{M}$ ), were determined by flow injection analysis with a QuickChem 8500 Automated Ion Analyzer.

\section{Phytoplankton}

One liter from each replicate sample was filtered through stacked mesh (to retain cells $>5 \mu \mathrm{m}$ ) and Whatman GF/F filters (nominal pore size $0.4 \mu \mathrm{m}$, to retain cells $<5 \mu \mathrm{m}$ ), allowing the examination of size fractionated phytoplankton biomass. Filters were frozen and stored at $-80^{\circ} \mathrm{C}$ prior to analysis on an Algilent 1200 series High Pressure Liquid Chromatography (HPLC) system via the gradient elution procedure of Van Heukelem and Thomas (2001) in the environmental chemistry laboratory at SARDI SAASC.

One litre from each replicate sample was fixed with Lugol's iodine solution. Enumeration and identification of phytoplankton to genus or species level was carried out using traditional taxonomic methods by Microalgal Services (Ormond, VIC, Australia).

TABLE 2 | Station locations and water sampling dates.

\begin{tabular}{lccccc}
\hline & \multicolumn{2}{c}{ Location } & & \multicolumn{2}{c}{ Sampling date } \\
\cline { 2 - 3 } Station & Latitude (S) & Longitude (E) & & 3/04/2013 & $\mathbf{1 9 / 0 4 / 2 0 1 3}$ \\
\hline West Beach & $34^{\circ} 57.734^{\prime}$ & $138^{\circ} 28.862^{\prime}$ & & Yes & \\
Port Stanvac & $35^{\circ} 05.331^{\prime}$ & $138^{\circ} 28.789^{\prime}$ & & Yes & Yes \\
Port Noarlunga & $35^{\circ} 08.724^{\prime}$ & $138^{\circ} 27.551^{\prime}$ & & Yes & Yes \\
Maslin Beach & $35^{\circ} 13.911^{\prime}$ & $138^{\circ} 27.750^{\prime}$ & & & Yes \\
Sellicks Beach & $35^{\circ} 18.596^{\prime}$ & $138^{\circ} 26.236^{\prime}$ & & Yes \\
Myponga Beach & $35^{\circ} 22.085^{\prime}$ & $138^{\circ} 23.104^{\prime}$ & & Yes \\
Carrickalinga & $35^{\circ} 24.757^{\prime}$ & $138^{\circ} 19.327^{\prime}$ & & Yes
\end{tabular}




\section{Remote-Sensed Data \\ Sea Surface Temperatures}

Sea surface temperature (SST) anomaly maps of Australia displaying satellite data (SA Integrated Marine Observing System) were sourced from the Commonwealth Scientific and Industrial Research Organisation (CSIRO) website: http: //www.cmar.csiro.au/remotesensing/oceancurrent/sst_anom/.

SST anomaly data compares a 6-day average SST to the historical average SST at the same time of year. The waters of South Australia's gulfs are generally vertically well-mixed (Nunes Vaz et al., 1990; Middleton and Bye, 2007), so SST is reflective of the water column temperature.

\section{Chlorophyll a Concentrations}

Remote sensed chlorophyll a concentrations were sourced for the period 6-14 March 2013 using the Giovanni online data system, developed and maintained by the NASA GES DISC ${ }^{1}$, and were compared to in situ measurements obtained from the SA Integrated Marine Observing System, and ground-truthed with pigment data from this study.

\section{Fish and Abalone Diagnostics \\ Fish Necropsy}

Fish were generally found dead, placed on ice (not frozen) and couriered to the South Australian animal health laboratories (Gribbles Veterinary Pathology). Species reported and collected are outlined in Table 3.

Fish samples were immediately processed when they arrived at the laboratory. A total of 102 fish were submitted to the laboratory (Table 3). Of those, 25 appeared suitable for histopathology and microbiology. Eight of these fish were subsequently useful for histopathological analyses and interpretation with minimal postmortem deterioration (Table 3). The eight fish identified to be appropriate for meaningful histopathology were Ringed Toad fish (Omegophora armilla), Ornate Cowfish (Aracana ornate), Hulafish (Trachinops spp.), Sweep (Scorpis spp.), Sea Mullet (Mugil cephalus), Degans Leatherjacket (Thamnaconus degeni) and two Toothbrush Leatherjacket (Acanthaluteres vittiger). Live fish were euthanized prior to necropsy. Following necropsy examination and collection of swabs for bacterial culture, fish samples were processed for histopathology, bacterial culture and polymerase chain reaction (PCR) techniques.

\section{Abalone Necropsy}

Abalone were immediately processed when they arrived at the laboratory. A total of 60 abalone were submitted to the laboratory, which were collected from the Beachport and Port McDonnell areas on the South Coast of South Australia and Point Drummond on the Eyre Peninsula from January to May 2013 (Table 4). Of those, 47 abalone (36 blacklip abalone and 11 greenlip abalone) were deemed appropriate for necropsy and shucked and examined. These 47 abalone were collected moribund or fresh dead by field staff during site visits. Of these, 42 abalone were determined to be appropriate for histopathological analyses, while PCR to detect abalone viral ganglioneuritis (AVG)

\footnotetext{
${ }^{1}$ http://disc.sci.gsfc.nasa.gov/giovanni/
}

was undertaken on 31 abalone. Culture of pedal vesicles/nodules for aerobic bacteria was undertaken on a pooled sample from three abalone.

\section{Histopathology}

Fish were dissected and key organs (gills, all internal organs, brain, and skin and muscle) were collected and fixed in 10\% seawater buffered formalin. Abalone were dissected and key organs (mouthparts and surrounding ganglia and nerve bundles, pedal tissue and pedal nerves, mantle, gills, hypobranchial glands, kidneys, digestive gland and various parts of the digestive system) were fixed in $10 \%$ seawater buffered formalin. Samples were processed using standard histological techniques, embedded in paraffin wax, and sectioned at $5 \mu \mathrm{m}$ using a microtome. Sections were stained with hematoxylin and eosin (H\&E).

Sections were assessed using compound microscope and image analyses software (OPTIMAS 6.5). Photomicrographs were taken of each organ at $4-40 \times$ magnification. Two sections per slide were assessed targeting key organs, while multiple slides (two or more) per animal were assessed. The primary interest was viral-like infected cells, immune reactions, pathologies and parasites.

\section{PCR}

Blacklip and greenlip abalone were dissected, and the pedal ganglia were immediately fixed in $90 \%$ ethanol. Samples were sent to the Fish Diseases Laboratory at the CSIRO Australian Animal Health Laboratory (Geelong, Victoria) for AVG PCR analysis.

\section{Bacterial Culture}

Gill and kidney swabs from eight fish received alive or recently dead were collected for routine culture for aerobic and enterobacterial fish pathogens. Swabs of pedal vesicles or nodules from the five abalone with gross evidence of pedal vesicles were cultured for aerobic bacteria.

\section{Data Analyses}

Data values are presented as mean \pm standard error (SE). Where possible, data from water samples collected during this study were compared to relevant long-term monitoring data. This included data collected from waters off Port Stanvac in April 2008 (provided by Tim Kildea, SA Water, hereafter termed the SA Water monthly mean), and monthly data for April from the SA EPA monitoring station off Port Noarlunga covering the period from $1997-2007^{2}$.

\section{RESULTS}

\section{Water}

\section{Water Temperature}

Between January and March 2013, South Australia was subject to a marine heatwave, with fluctuating SST anomalies up to $5^{\circ} \mathrm{C}$ greater than the historical average (Figure 2). The warmer than average water temperature covered a wide geographic range

\footnotetext{
${ }^{2}$ www.epa.sa.gov.au
} 
TABLE 3 | Fish samples collected and submitted to the laboratory and other reported fish mortalities during the 2013 fish kill event.

\begin{tabular}{|c|c|c|c|}
\hline Fish species & Date collected & Location & Alive/dead ${ }^{1}$ \\
\hline \multirow[t]{4}{*}{ Degens Leatherjacket (Thamnaconus degeni) } & 3/03/2013 & Port Neil & 17 dead \\
\hline & $19 / 03 / 2013$ & Moonlight Bay & 9 dead \\
\hline & $1 / 04 / 2013$ & Port Noarlunga & 5 dead \\
\hline & $5 / 04 / 2013^{*}$ & O'Sullivans beach & 1 alive \\
\hline Silverbelly (Parequula melbournensis) & 3/03/2013 & Port Neil & 2 dead \\
\hline Pygmy Leatherjacket (Brachaluteres jacksonianus) & 3/03/2013 & Port Neil & 1 dead \\
\hline Western Talma (Chelmonops curiosus) & $1 / 04 / 2013$ & Port Noarlunga & 1 dead \\
\hline Ringed Toad fish (Omegophora armilla) & 3/04/2013* & O'Sullivans beach & 1 dead \\
\hline Ornate cowfish (Aracana ornate) & 3/04/2013* & O'Sullivans beach & 1 dead \\
\hline Hulafish (Trachinops spp.) & 3/04/2013* & Port Noarlunga & 1 alive \\
\hline Unidentified fish species & $24 / 04 / 2013$ & Sellicks beach & 7 dead \\
\hline \multicolumn{4}{|l|}{ Other reported mortalities } \\
\hline \multicolumn{4}{|l|}{ King George Whiting (Sillaginodes punctatus) } \\
\hline \multicolumn{4}{|l|}{ Yellowfin Whiting (Sillago schomburgkii) } \\
\hline \multicolumn{4}{|l|}{ Southern School Whiting (Sillago bassensis) } \\
\hline \multicolumn{4}{|l|}{ Black Bream (Acanthopagrus butcheri) } \\
\hline \multicolumn{4}{|l|}{ Pink Snapper (Chrysophrys auratus) } \\
\hline \multicolumn{4}{|l|}{ Dusky Morwong (Dactylophora nigricans) } \\
\hline \multicolumn{4}{|l|}{ Sea Sweep (Scorpis aequipinnis) } \\
\hline \multicolumn{4}{|l|}{ Common Bullseye (Pempheris multiradiata) } \\
\hline \multicolumn{4}{|l|}{ Pipe fish (Family: Syngnathidae) } \\
\hline Blue Shark (Prionace glauca) & & & \\
\hline
\end{tabular}

${ }^{1}$ Indicates fish were submitted either live or dead to the South Australian animal health laboratories (Gribbles Veterinary Pathology). * indicate samples that were fresh enough for meaningful histopathological assessment.

across both gulfs and shelf waters. The SST fluctuated by up to $5^{\circ} \mathrm{C}$ over days (for example see Figures 2D,E), peaking during the first two weeks of March 2013 at $23^{\circ} \mathrm{C}$ on the north coast of Kangaroo Island (unpublished data, Yumbah Aquaculture), approximately $27^{\circ} \mathrm{C}$ at the entrance of the Gulfs, and approximately $30^{\circ} \mathrm{C}$ in shallow coastal waters ${ }^{3}$. Water temperature data loggers also recorded temperature fluctuations of $3-5^{\circ} \mathrm{C}$ over days (unpublished data, SARDI and Yumbah Aquaculture). For comparison, during summer historical average SST at the entrance of Spencer Gulf reaches approximately $21.5^{\circ} \mathrm{C}$ and at the top of Spencer Gulf reaches approximately $24.5^{\circ} \mathrm{C}$ (Roberts et al., 2012), peaking at up to $28^{\circ} \mathrm{C}$ at the very top of the gulf (Shepherd and Baker, 2014).

\footnotetext{
${ }^{3}$ http://www.cmar.csiro.au/remotesensing/oceancurrent/sst_s/2013/
}

\section{Chlorophyll}

The average chlorophyll concentration calculated using remote sensed satellite data $^{4}$ for the period 6-14 March 2013 are shown in Figure 3A. The average chlorophyll concentration during this period is similar to other summertime values, including the average calculated using remote sensed data for the period 26 February to 29 March 2012 (Figure 3B). Chlorophyll concentrations measured from phytoplankton samples collected at West Beach, Port Stanvac, Port Noarlunga, Maslin Beach, Sellicks Beach, Myponga Beach, and Carrickalinga Beach indicate chlorophyll concentrations typically ranged between 0.5 and $0.9 \mathrm{mg} \mathrm{m}^{3}$ (Figure 4).

\footnotetext{
${ }^{4}$ http://disc.sci.gsfc.nasa.gov/giovanni/
} 
TABLE 4 | Blacklip (Haliotis rubra) and Greenlip (Haliotis laevigata) abalone samples submitted to the laboratory, which were collected by fishers that reported mortalities or by government (SARDI) staff during site investigations.

\begin{tabular}{lcll}
\hline Species & Date collected & Location & Alive/dead \\
\hline Blacklip abalone & $17 / 01 / 2013$ & Ringwood reef (SZAF) & 9 alive/3 dead \\
Blacklip abalone & $22 / 02 / 2013$ & Beachport (SZAF) & 4 dead \\
Blacklip abalone & $23 / 02 / 2013$ & Port Macdonnell (SZAF) & 4 dead \\
Blacklip abalone & $23 / 02 / 2013$ & Port Macdonnell (SZAF) & 3 dead \\
Blacklip abalone & $23 / 02 / 2013$ & Port Macdonnell (SZAF) & 4 dead \\
Greenlip abalone & $23 / 03 / 2013$ & Thorny passage, Pt Lincoln & 1 dead \\
& & (WZAF) & \\
Greenlip abalone & $23 / 04 / 2013$ & McLaren Point (WZAF) & 10 dead \\
Blacklip abalone & $23 / 04 / 2013$ & McLaren Point (WZAF) & 1 dead \\
Greenlip abalone & $23 / 04 / 2013$ & Taylor Island (WZAF) & 5 alive \\
Abalone species & $4 / 05 / 2013$ & Point Drummond (WZAF) & 2 dead \\
Abalone species & $7 / 05 / 2013$ & Point Drummond (WZAF) & 3 dead \\
Abalone species & $7 / 05 / 2013$ & Point Drummond (WZAF) & 11 dead \\
\hline
\end{tabular}

SZAF, southern zone abalone fishery, WZAF, western zone abalone fishery. ${ }^{1}$ Indicates abalone were collected either live or dead. ${ }^{2}$ Samples collected were from a control site.

\section{Nutrient Concentrations}

Macro-nutrient concentrations were generally low (Figure 5). Concentrations of $\mathrm{NO}_{x}$ and $\mathrm{PO}_{4}$ were predominately below detection limits. These levels are much lower than the SA Water monthly mean $\left(\mathrm{NO}_{x} 0.36 \pm 0.0 \mu \mathrm{M}, n=8 ; \mathrm{PO}_{4} 0.16 \pm 0.0 \mu \mathrm{M}\right.$, $n=8$ ), and well below the Environment Protection Authority (EPA) long-term mean $\left(\mathrm{NO}_{x}=0.74 \pm 0.13 \mu \mathrm{M}, n=11\right) . \mathrm{NH}_{3}$ concentration decreased markedly from 0.5 to $0.6 \mu \mathrm{M}$ on 3 April to $<0.2 \mu \mathrm{M}$ on 19 April, with concentrations in some samples below detection limits. $\mathrm{NH}_{3}$ levels on 3 April were higher than the SA Water monthly mean $(0.36 \pm 0.0 \mu \mathrm{M}$, $n=8$ ), but were approximately half the EPA long-term mean $(1.24 \pm 0.38 \mu \mathrm{M}, n=10)$. Silica concentrations were $\sim 0.6-$ $0.8 \mu \mathrm{M}$ on both sampling dates, although levels at Port Noarlunga decreased from $\sim 0.8$ to $\sim 0.4 \mu \mathrm{M}$ from 33 April to 19 April. These levels are approximately $1 / 3$ the SA Water monthly mean $(2.42 \pm 0.14 \mu \mathrm{M}, n=12)$.

\section{Phytoplankton Biomass, Abundance and Community Composition}

Patterns in phytoplankton biomass, measured as chlorophyll a, varied between sampling dates (Figure 4). On both sampling dates, however, the majority of phytoplankton biomass was in the small size fraction (i.e., cells $<5 \mu \mathrm{m}$ in diameter). Total chlorophyll a concentrations ranged between 0.4 and $0.9 \mu \mathrm{g} \mathrm{L}^{-1}$, but were generally $\sim 0.6 \mu \mathrm{g} \mathrm{L}^{-1}$. These values are similar to the SA Water monthly mean $\left(0.65 \pm 0.03 \mu \mathrm{g} \mathrm{L}^{-1}, n=8\right)$, the EPA long-term mean $\left(0.81 \pm 0.10 \mu \mathrm{g} \mathrm{L}^{-1}, n=10\right)$, and concentrations measured off Port Stanvac in April 2010 and April $2011(\sim 0.4 \mu \mathrm{g}$ $\mathrm{L}^{-1}$, van Ruth, 2010, 2012). There was a distinct north - south pattern in chlorophyll a concentrations on 3 April which had reversed by 19 April. Chlorophyll a concentrations increased at Port Stanvac from $\sim 0.7 \mu \mathrm{g} \mathrm{L}^{-1}$ on 3 April to $\sim 0.9 \mu \mathrm{g} \mathrm{L}^{-1}$ on 19 April, while concentrations at Port Noarlunga decreased from $\sim 0.9 \mu \mathrm{g} \mathrm{L}^{-1}$ on 3 April to $\sim 0.6 \mu \mathrm{g} \mathrm{L}^{-1}$ on 19 April. Biomass in the small size fraction remained relatively steady at $\sim 0.6 \mu \mathrm{g}$ $\mathrm{L}^{-1}$ on both sampling dates, though there was an increase at Port Stanvac to $\sim 0.8 \mu \mathrm{g} \mathrm{L}^{-1}$ on 19 April. From 3 April to 19 April biomass in the large size fraction had decreased by about half to $<0.1 \mu \mathrm{g} \mathrm{L}^{-1}$.

Patterns in phytoplankton abundance between sampling dates mirrored patterns in phytoplankton biomass (Figure 6). This is also consistent with previous findings for the waters off Port Stanvac (van Ruth, 2010, 2012). However, there was variation between sampling dates in both total abundances and dominant taxa in the community. Total phytoplankton abundances ranged between 250,000 and 550,000 cells $\mathrm{L}^{-1}$ on 3 April, but had decreased to 100,000 to 200,000 cells $\mathrm{L}^{-1}$ by 19 April, largely due to a decrease in diatom abundance. Larger diatoms dominated the community on 3 April, while the community was dominated by "other" phytoplankton (small flagellates) on 19 April.

Examination of selected marker pigments as a fraction of chlorophyll a revealed the large size fraction ( $>5 \mu \mathrm{m}$ in diameter) of phytoplankton biomass was dominated by larger diatoms (indicated by a high fraction of Fucoxanthin) and dinoflagellates (indicated by a high fraction of Peridinin) (Figure 4). However, while peridinin was more prominent on 3 April, it was only detected at Port Stanvac on 19 April. Fucoxanthin was detected at all stations on both sampling dates, but in slightly lower concentrations on 19 April. The small size fraction $(<5 \mu \mathrm{m}$ in diameter) was dominated by chrysophytes and raphidophytes (Fucoxanthin), cryptophytes (alloxanthin), haptophytes (19'hexanoyloxyfucoxanthin), cyanobacteria (Zeaxanthin) and prasinophytes (Chl b) (Figure 4). Prasinophytes were most dominant on both sampling dates, with haptophytes increasing in the community on 19 April. Dominant marker pigments and pigment ratios are consistent with previous findings for waters off Port Stanvac (van Ruth, 2010, 2012).

Phytoplankton community composition from abundance counts varied greatly between sampling dates. On 3 April, diatoms dominated the community. The most abundant diatom was Pseudo-nitzschia cf. galaxiae which was present at concentrations of between approximately 50,000 and 250,000 cells $\mathrm{L}^{-1}$. Other dominant diatoms on this date included Dactyliosolen antarcticus, Leptocylindrus danicus, Nitzschia spp., and Chaetoceros spp., all of which were present in concentrations of 7,000 to 20,000 cells $\mathrm{L}^{-1}$. Chaetoceros coarctatus, a diatom species characterized by barbs on the setae, was detected in low numbers $\left(\sim 200-2000\right.$ cells $\left.\mathrm{L}^{-1}\right)$ in all samples. Dominant dinoflagellates included Azadium obesum ( 6,000-30,000 cells $\left.\mathrm{L}^{-1}\right)$, Gymnodinium spp. ( $\sim 30,000$ cells $\left.\mathrm{L}^{-1}\right)$, Gyrodinium spp. $\left(\sim 5,000-10,000\right.$ cells $\left.L^{-1}\right)$ and Heterocapsa rotundata $(\sim 5,000$ to 15,000 cells $\left.\mathrm{L}^{-1}\right)$. Karenia mikimoto $i$ was detected, but in very low numbers. Other phytoplankton to dominate the community included the haptophyte Chrysochromulina spp., the cryptophyte Plagioselmis prolonga, and the prasinophyte Pyramimonas spp., all of which were present at between 5,000 and 30,000 cells $\mathrm{L}^{-1}$. On 19 April, when diatom abundances had decreased (Figure 6), Chaetoceros spp. dominated the diatom community ( 5,000 to 20,000 cells $\mathrm{L}^{-1}$ ), with C. coarctatus again present at low abundances $\left(\sim 200-2000\right.$ cells $\left.\mathrm{L}^{-1}\right)$. Pseudo-nitzschia cf. 


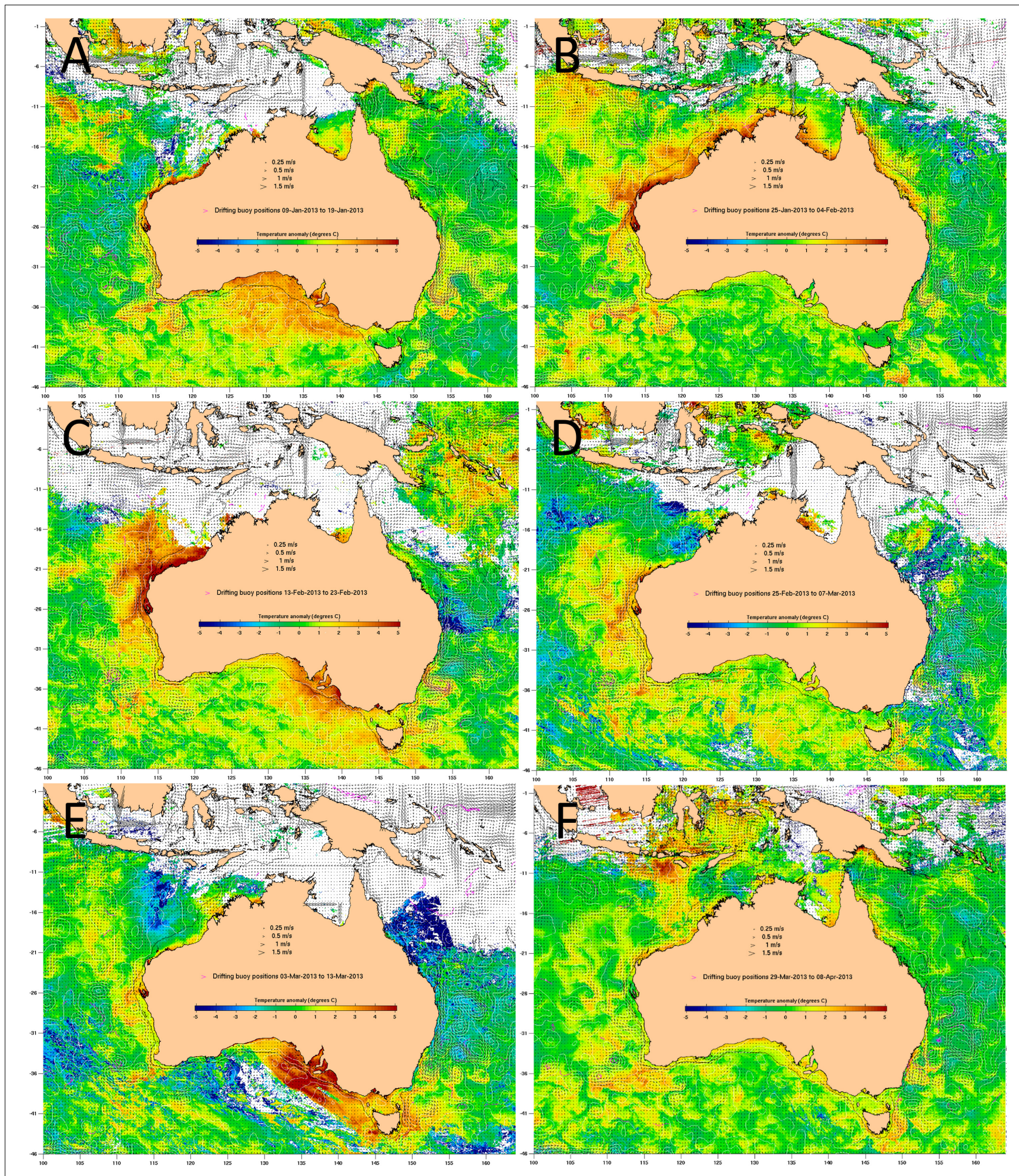

FIGURE 2 | Sea surface temperature (SST) anomaly, which compares a 6-day average SST to the historical average SST at the same time of year, for (A) 12-17 January 2013, (B) 28 January to 2 February 2013, (C) 16-21 February 2013, (D) 27 February to 4 March 2013, (E) 6-11 March 2013 and (F) 1-6 April 2013. SST ranges from colder $\left(-5^{\circ} \mathrm{C}\right.$, blue) than the historical average to warmer $\left(+5^{\circ} \mathrm{C}\right.$, red) than the historical average. Source:

http://www.cmar.csiro.au/remotesensing/oceancurrent/sst_anom/; accessed June 2019, where the drifting buoy positions for 10 days were used to determine the 6 days SST anomaly. 

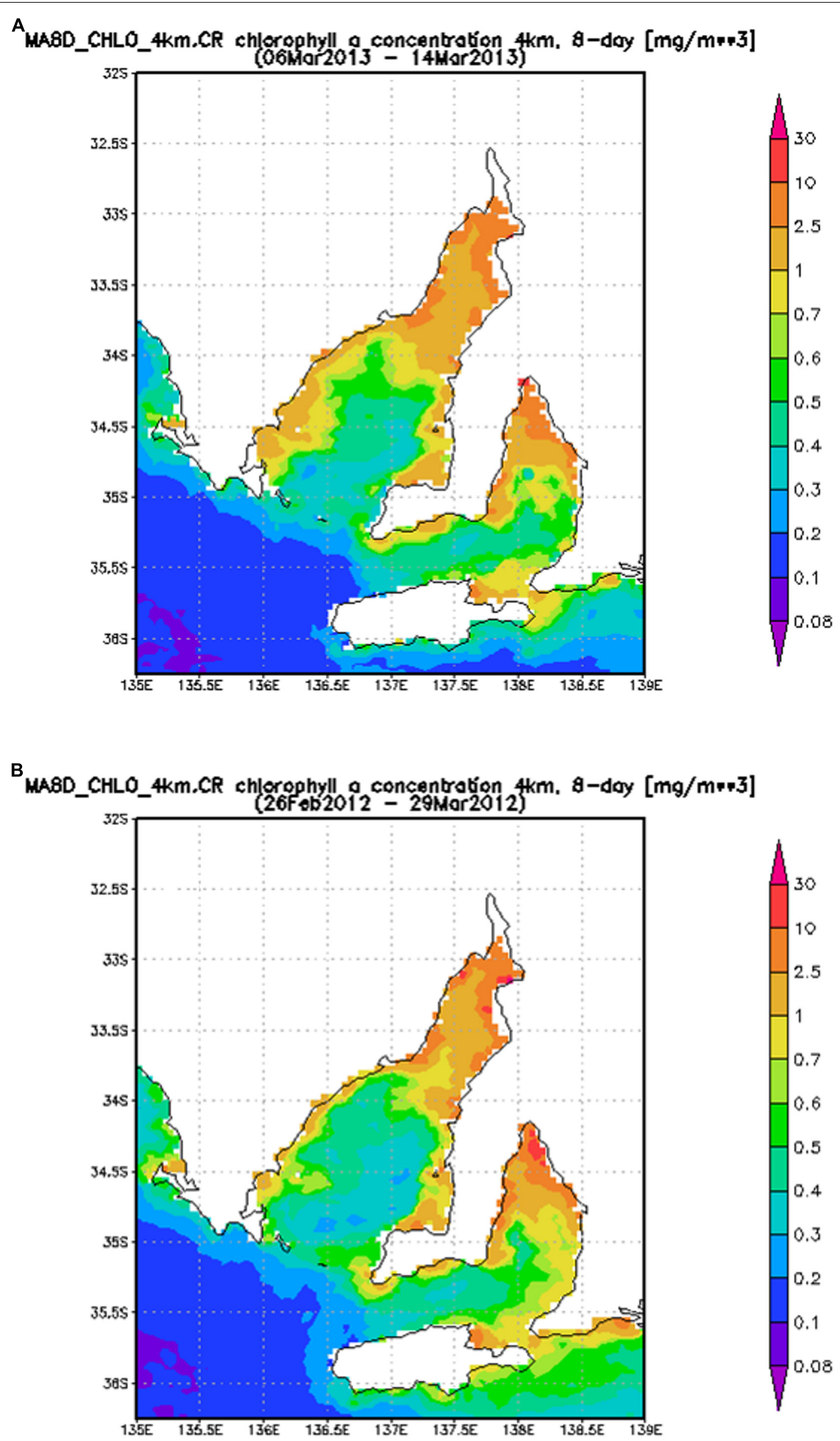

FIGURE 3 | Average chlorophyll concentration ( $\mathrm{mg} \mathrm{m}^{3}$ ) from 6 to 14 March 2013 (A) and 26 February to 14 March 2012 (B). 


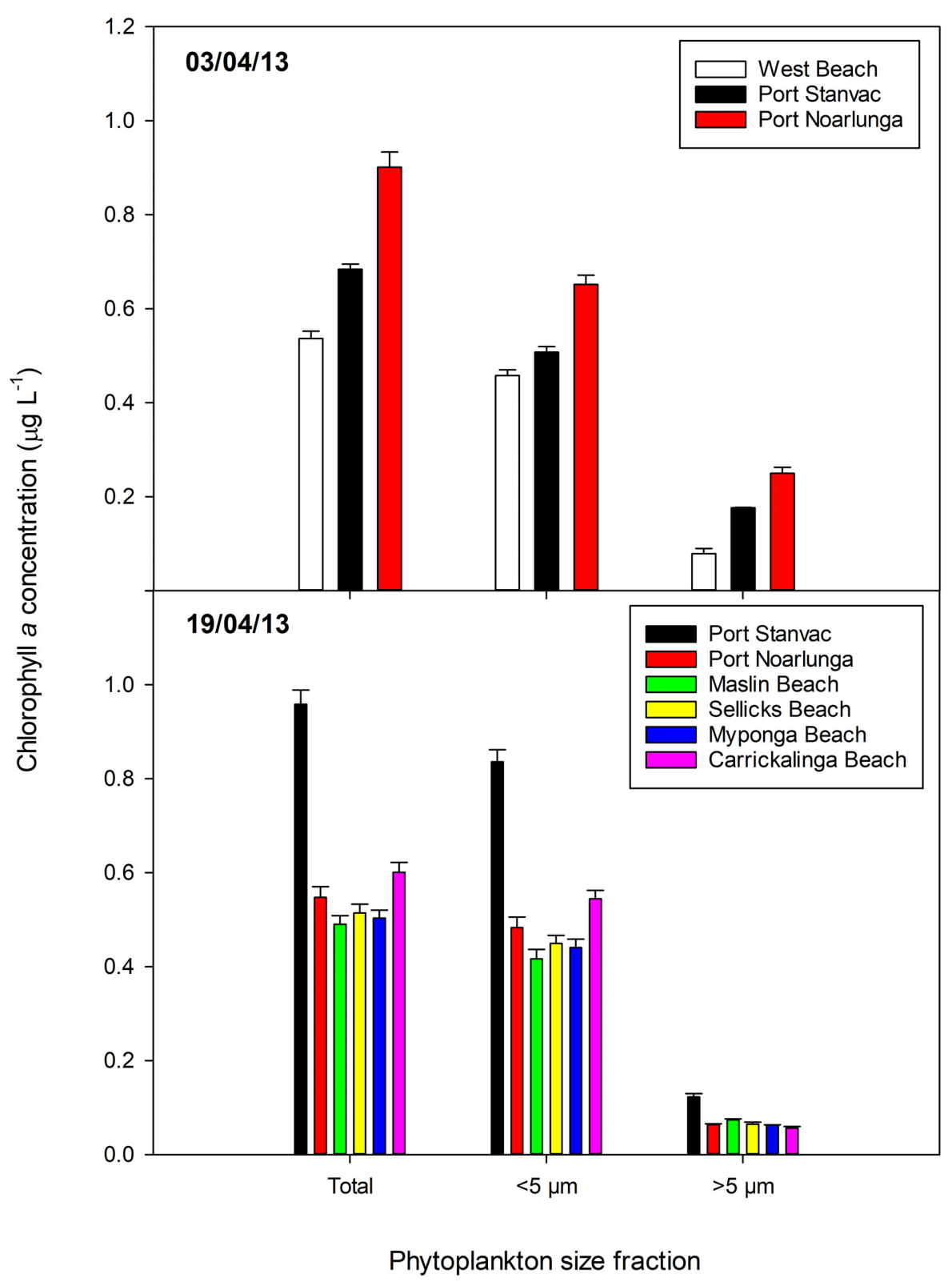

FIGURE 4 | Total chlorophyll a concentrations, and concentrations in the small ( $<5 \mu \mathrm{m}$ ) and large ( $>5 \mu \mathrm{m})$ size fractions of phytoplankton biomass in samples collected in Gulf St Vincent on 3 and 19 April 2013. Mean \pm standard error. Station locations are displayed in Table 2.

galaxiae were also present in reduced numbers $(\sim 5,000$ to 15,000 cells $\mathrm{L}^{-1}$ ). The dinoflagellates were dominated by Gymnodinium spp. and Heterocapsa rotundata (both $\sim 5,000$ to 20,000 cells $\left.\mathrm{L}^{-1}\right)$. Other dominant phytoplankton on Aril 19th included the haptophyte Chrysochromulina spp. $\left(\sim 15,000\right.$ to 55,000 cells $\left.\mathrm{L}^{-1}\right)$, the cryptophytes Plagioselmis prolonga ( $\sim 5,000$ to 15,000 cells $\left.\mathrm{L}^{-1}\right)$ and Hemiselmis spp. $\left(\sim 10,000\right.$ to 25,000 cells $\left.\mathrm{L}^{-1}\right)$, and the prasinophyte Pyramimonas spp. ( 5,000 to 20,000 cells $\left.\mathrm{L}^{-1}\right)$.

Several phytoplankton species which may be potentially harmful/toxic to fish were identified in the samples collected for this study, including C. coarctatus. Other species identified that have been previously linked to fish-kills include Karenia mikimotoi, Heterosigma sp., Dictyocha octonaria, and Takayama sp., although these phytoplankton were only rarely present, and in low concentrations $\left(<500\right.$ cells $\left.\mathrm{L}^{-1}\right)$.

\section{Fish}

A total of 39 reported fish mortalities occurred from 25 January 2013 to 24 April 2013 across the State (Figure 1 and Table 1). The majority of reports involved multispecies, with the majority of fish affected being temperate smallbodied benthic species (Table 3). Degens Leatherjackets were noticeably the most numerous fish reported dead during this 


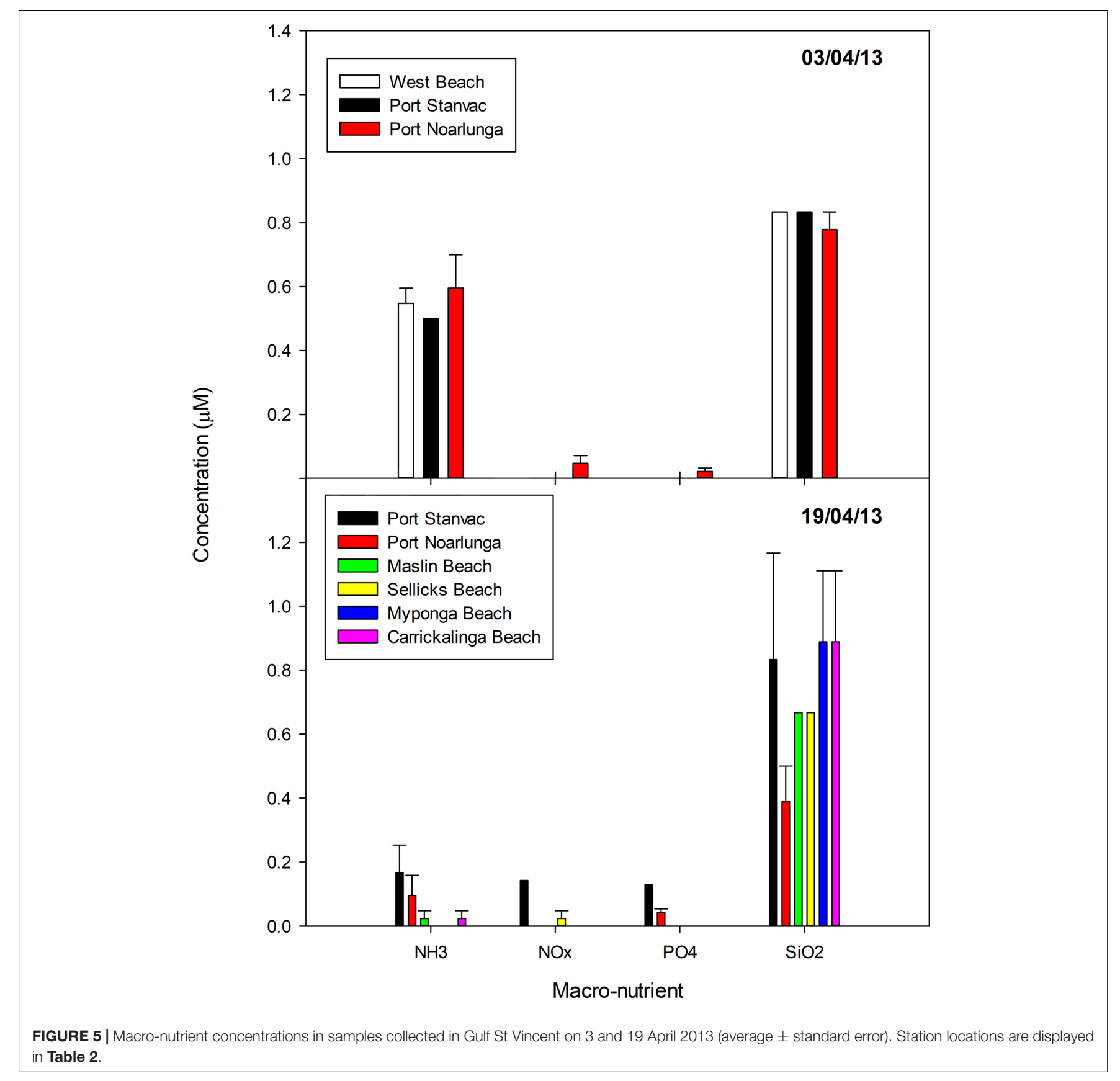

fish kill. The large majority of reported mortalities were verified through site visits, photographic or video evidence and/or detailed reports provided from reputable sources (e.g., government personnel or dive club). Accurate numbers of dead fish were documented for some sites across the State. Estimates of fish numbers that washed up onto beaches ranged from 100-2000 fish $/ \mathrm{km}$. Underwater video footage and diver observations demonstrated that large schools of Degens Leatherjackets, and other species, were apparently healthy and swimming through the murky green coastal waters. Only a few fish were observed to be unhealthy with signs of listing, spinning and poor swimming. Other observations included the gills of many dying and fresh dead fish haemorrhaged when handled.

Numerous different species washed up on metropolitan and country beaches (Table 3$)$. Dead or moribund fish $(n=102)$ collected in the field were submitted to the laboratory (Table 3 ). Of these, only 25 appeared suitable for histopathology and microbiology analyses. Post-mortem changes for 17 of these fish were too far advanced for meaningful interpretation, although similar pathologies to more suitable samples was noted. Eight fish that were received alive or that had died a few hours prior to necropsy provided meaningful histopathology and microbiology analyses. In these fish, moderate branchitis that presented as 


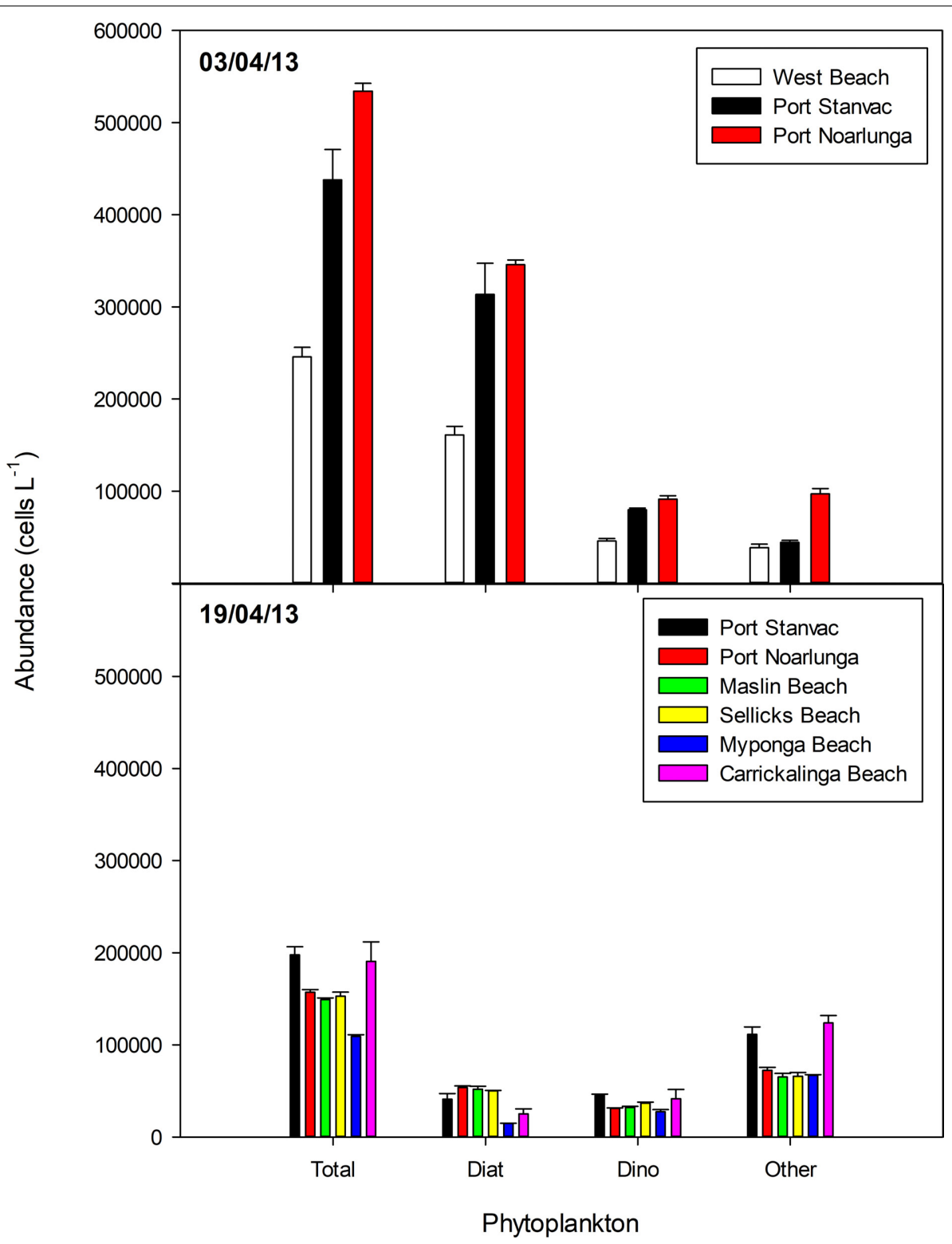

FIGURE 6 | Variation in mean phytoplankton abundance in samples collected in Gulf St Vincent on 3 and 19 April 2013. Error bars indicate standard error. Station locations are displayed in Table 2.

focal gill lesions (necrosis, epithelial hyperplasia and fusion of lamellae), high numbers of mucous and chloride cells, and associated bacteria were observed in the gills (Figures 7AE). Less than $\sim 10 \%$ of the gill structure was affected with focal lesions, which were generally 2-3 gill lamellae in size. While focal gill lesions and increased mucus production were evident, the large area of intact gill lamellae (non-lesion areas being $\sim 90 \%$ of the gill structure) suggested respiratory failure was an unlikely cause of death. There was also haemorrhagic inflammation suggestive of prolonged stress (infiltration of lymphocytes and pigmented macrophages). Of interest, some fragments of diatom-like debris were observed between the gill filaments and gill lamellae (Figures $\mathbf{8 A}, \mathbf{B}$ ). The size of those suspected diatom fragments (approximately 20-30 $\mu \mathrm{m}$ ) observed on histology matched well with the size of Chaetoceros coarctatus cells observed under light microscopy (Figure 9).

Other findings from the necropsy and histopathology included excess mucus over the gills, fraying of the gill filaments, splenomegaly and hepatomegaly in the toadfish. Gill congestion with excess mucus and petechial hemorrhages in the skin over the lateral body and at the base of the fins in the sweep and mullet. In the two leatherjacket species (Toothbrush and Degans) gill congestion and gill debris were also observed.

Bacterial culture of gills and kidneys yielded Vibrio spp., a group of opportunistic bacterial species. Bacterial infections were observed in liver, spleen, intestinal submucosa, brain, 

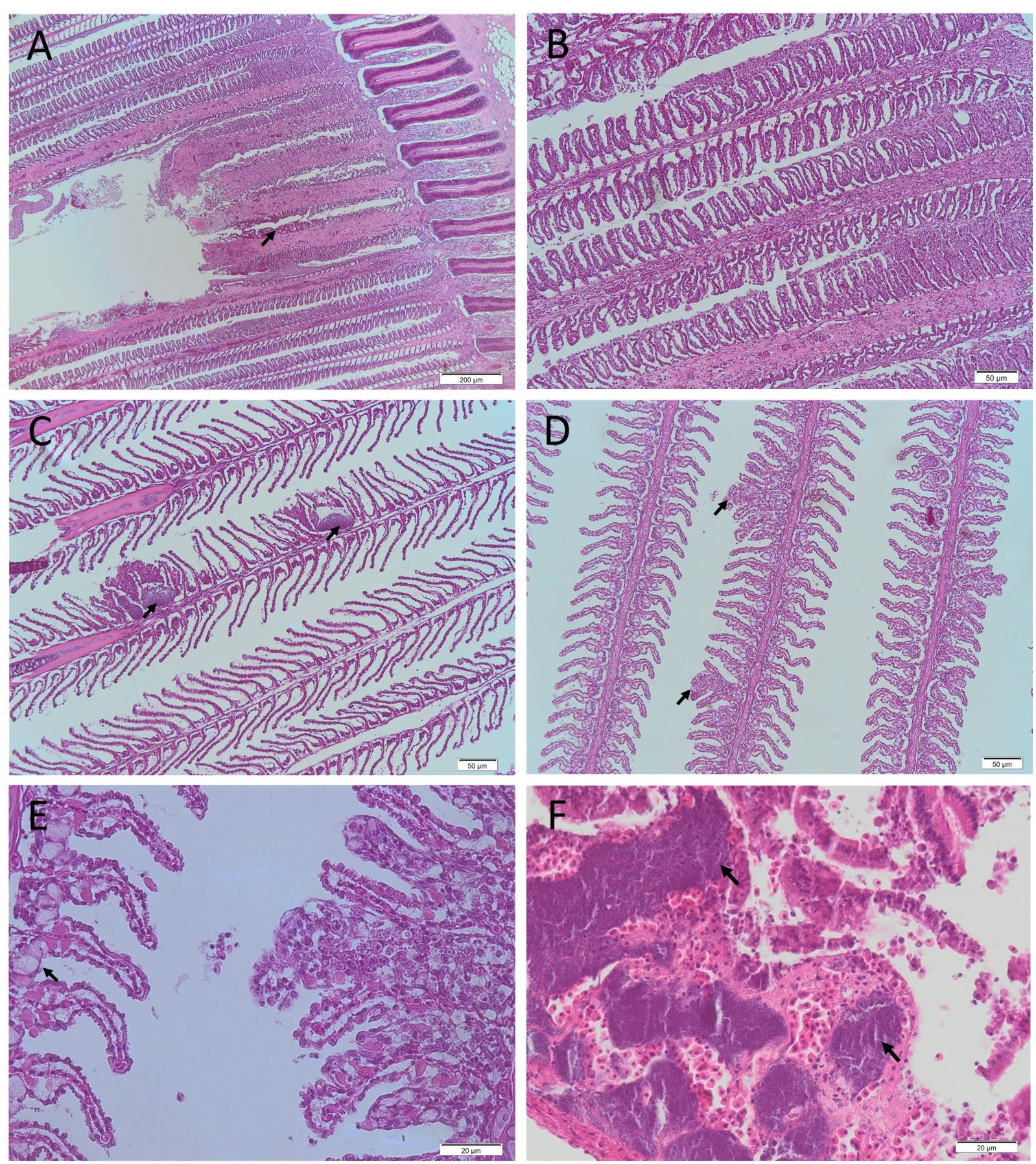

FIGURE 7 | Representative histological photomicrographs of fish gills (A-E) and kidney (F) from the 2013 fish kill. Necrotic gill lesion with gill filaments severely affected and associated hemorrhage (A; arrow; $4 \times$ magnification [mag.]), gill congestion (B; $10 \times$ mag.) and focal gill lesions with associated bacteria (C; arrow; $10 \times$ mag.) in a Sweep (Scorpis spp.) collected on the 4/04/2013. Focal hyperplastic gill lesions (D; arrows; $10 \times$ mag.) and focal hyperplastic gill lesion with associated mucous cell hyperplasia observed on adjacent gill filament (E; arrow; $40 \times$ mag.) in an Ornate Cowfish (Aracana ornate) collected on the 3/04/2013. Kidney with numerous bacterial emboli (arrows; F; $40 \times$ mag.) in a Hulafish (Trachinops spp.) collected on 3/04/2013.

gills and kidney (Figures 7C,F). Melanomacrophage centers in various tissues were prominent in many samples, which suggests prolonged stress. These findings suggest systemic bacteraemia/septicaemia was likely the cause of death.
Incidental findings included helminthal granulomatous enteritis and peritonitis in the toadfish, protozoal granulomatous nephritis in the ornate cowfish, pharyngeal ulceration in the mullet, granulomatous enteritis in one toothbrush leatherjacket 

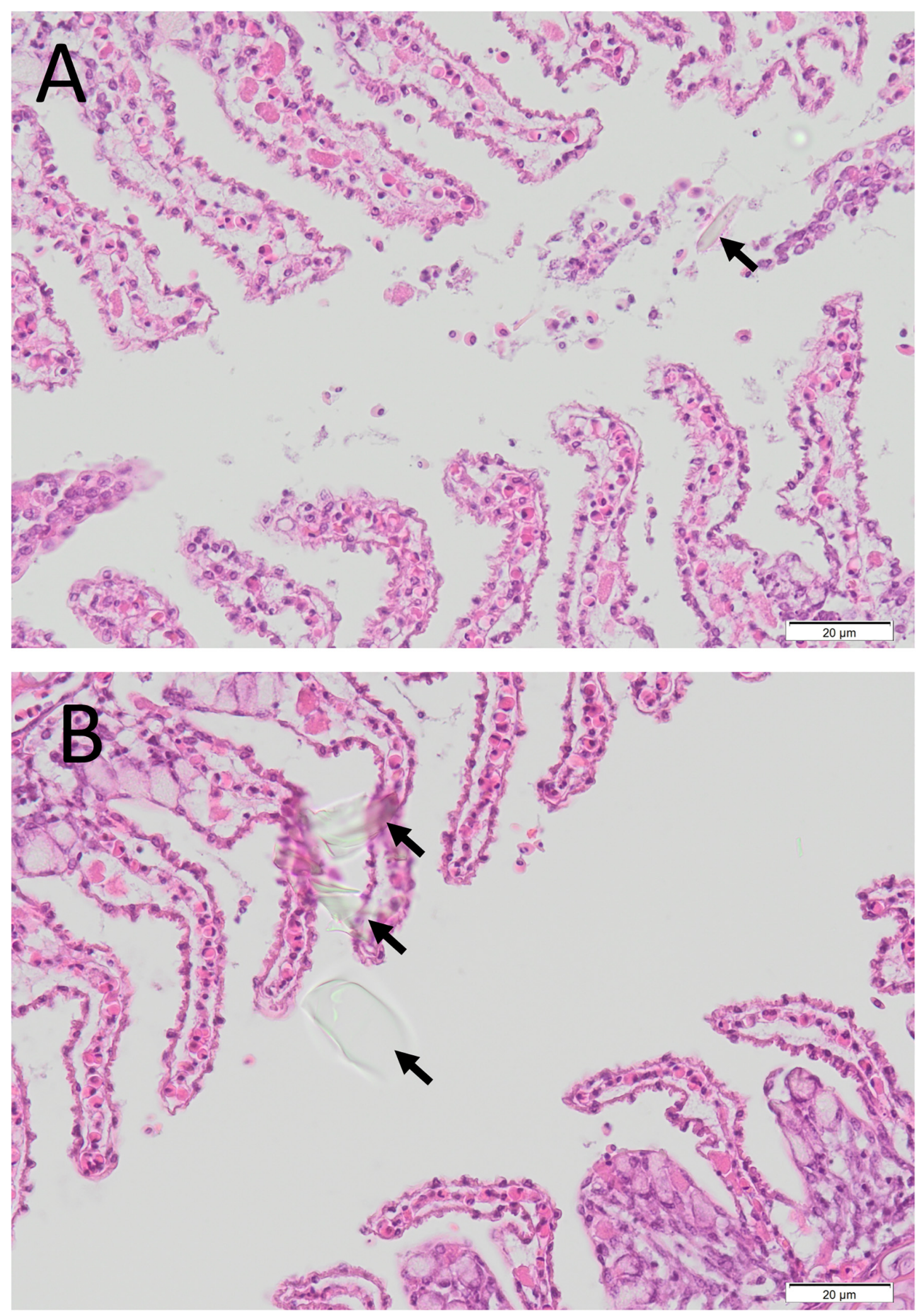

FIGURE 8 | Histological photomicrographs of the gill of an Ornate Cowfish (Aracana ornate) with diffuse epithelial hyperplasia and presence of cellular debris, including refractile diatom-like material (arrow), in the lamellar spaces (A), and similar extraneous debris in the lamellar space and over the surface of the gill epithelium (arrows) (B) $(40 \times$ mag.) collected on 3/04/2013. 


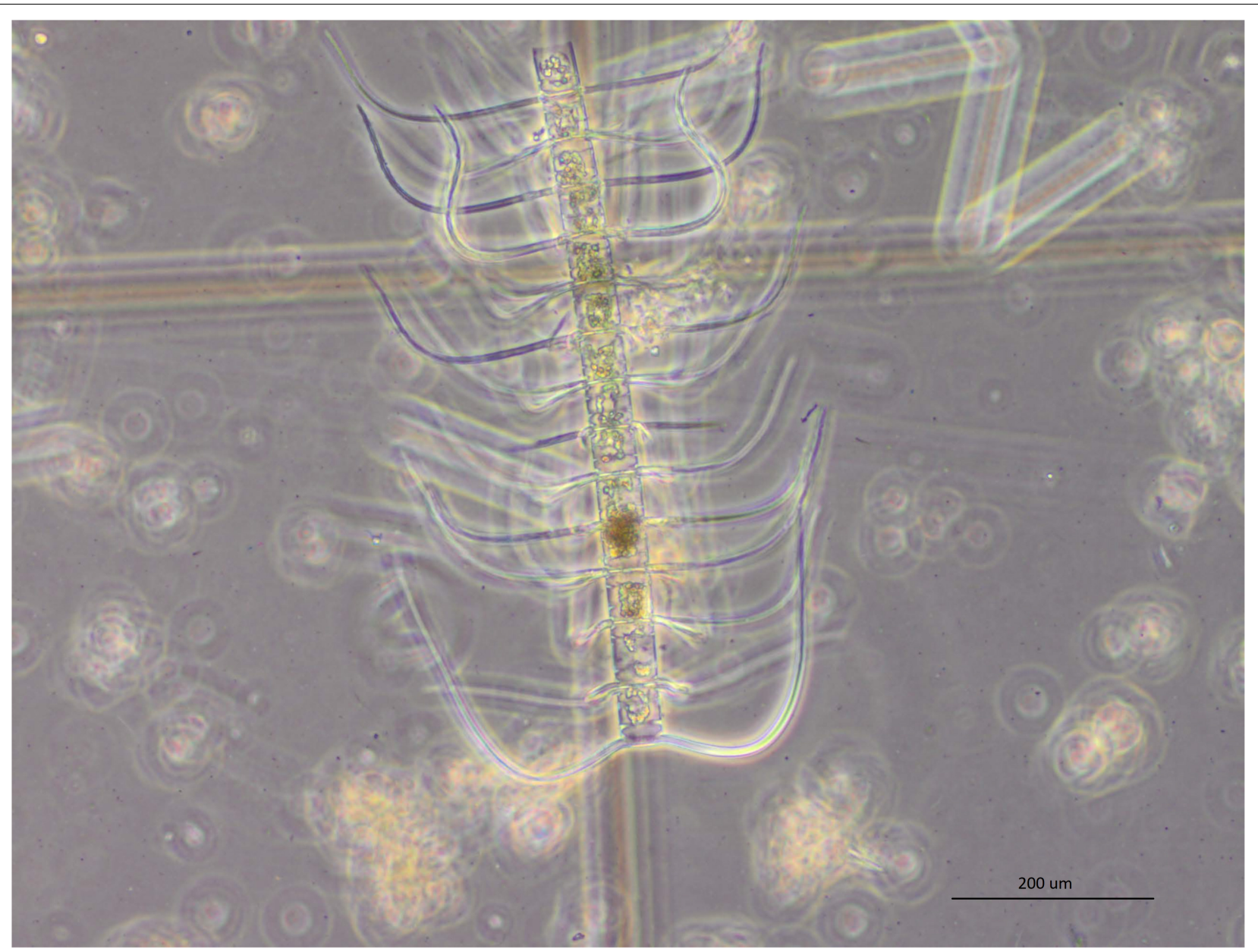

FIGURE 9 | A chain of 14 Chaetoceros coarctatus cells detected in water samples along the metropolitan Adelaide Coastline in April 2013 (20x mag.). A single cell of C. coarctatus typically has an apical axis of 25-45 $\mu \mathrm{m}$ and a transapical axis of 13-20 $\mu \mathrm{m}$ and armed with conspicuous spines. They can form long and robust chains typically of 12-16 cells long (Hasle and Syvertsen, 1997; Lee and Lee, 2011).

and an intra-abdominal isopod in a second toothbrush leatherjacket. Numerous types of parasites were also observed in necropsied fish including acanthocephalans (sweep and sea mullet), flukes (Ornate Cowfish), Kudoa and Trichodina (Toothbrush Leatherjacket). Parasites are common in wild caught fish, and were not likely associated with this fish kill as they varied between individual fish.

\section{Abalone}

Eleven abalone morbidity and mortality events were reported by commercial fishers from 11 January 2013 through to 4 May 2013 across the State (Figure 1 and Table 1). Generally, 5-70 moribund or dead abalone out of several hundred kilograms during one time point (incidental mortality) from one day fishing were reported. For example, one report was of 50 fresh dead abalone (out of $\sim 900 \mathrm{~kg}$ of healthy abalone harvested) on Ringwood Reef near Beachport, in the Southern Zone Abalone Fishery (SZAF), on 17 January 2013. Anecdotal evidence from SZAF commercial fishers suggested that over the summer mortality period, the cumulative mortality of abalone at some reef locations may have been up to 30-50\% (Mayfield et al., 2015). SARDI research divers confirmed the abalone mortalities and conditions at some locations around the State. Of note abalone mortalities ceased on 19 May 2013 at Ringwood Reef (SZAF) based on observations by SARDI research divers.

During the mortality event, diver (commercial fishers and researchers) observations included higher than normal temperatures, turbid waters, high amounts of dead and decaying detritus (largely seaweed) and lethargy of some abalone. These conditions may have been conducive to periods of hypoxia, particularly during slack or neap tides 5 . There was significant shell seaweed fouling and barnacle encrustations in all abalone and mild internal mudworm infestation in 11 abalone with mild associated damage of the retractor muscle in one of these. Single or multiple vesicles or nodules were seen in the foot of five abalone.

Multiple pedal abscesses/cysts or densely cellular foci were seen in 10 abalone amongst those examined in late February

${ }^{5}$ www.bom.gov.au 

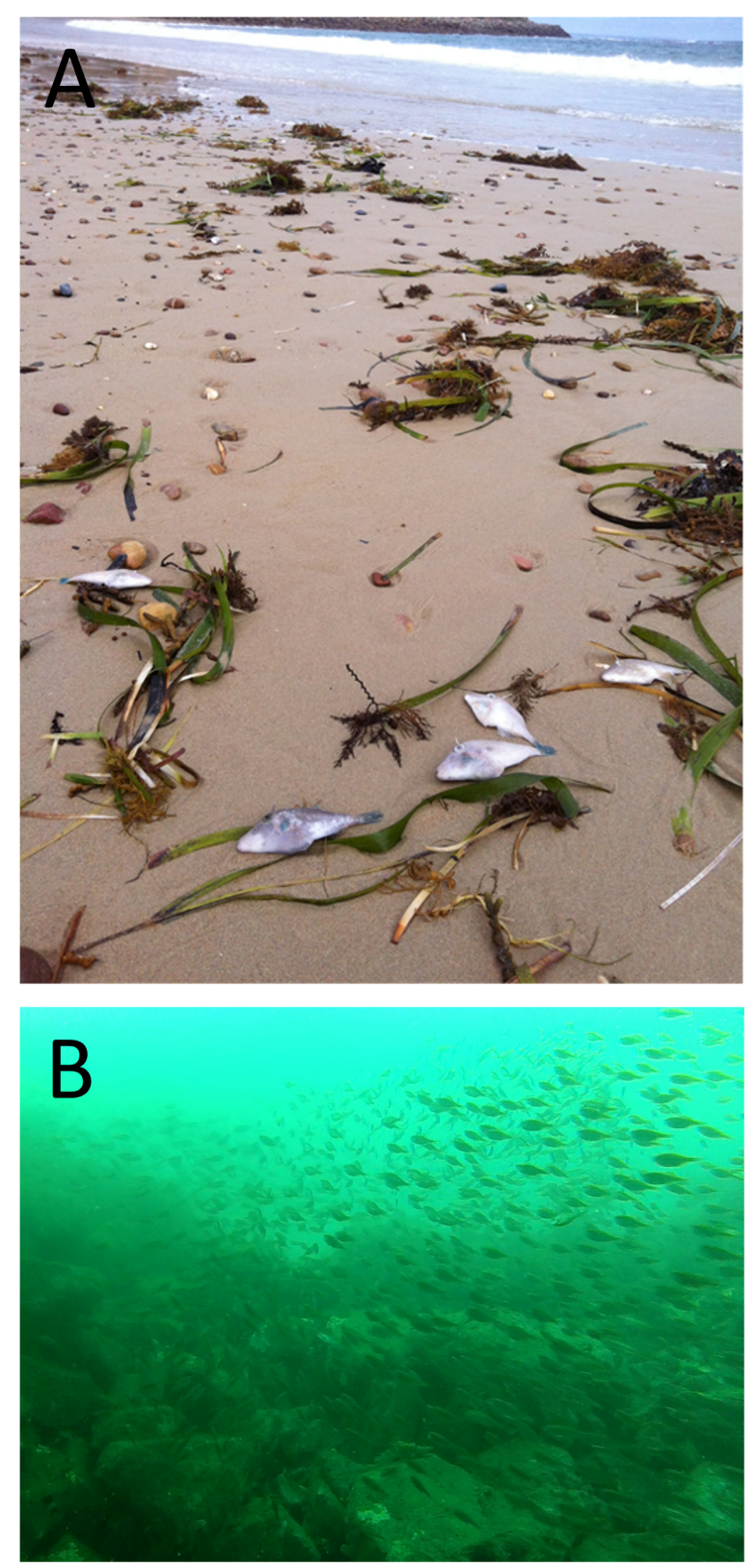

FIGURE 10 | Dead Degens Leatherjackets (Thamnaconus degeni) washed up at Port Noarlunga (A) and screenshots of underwater video footage taken on 4 April 2013 in the coastal waters of the Adelaide metropolitan coastline of large schools of apparently healthy Degens Leatherjackets (B).

and early May. The former consisted of an outer densely cellular layer of haemocytes and an inner lytic center and the latter constituted densely cellular aggregates of haemocytes. Numerous Gram-negative small rod shaped bacteria were seen in the lytic centers of many of the abscesses. No significant pathology was noted in any of the remaining tissues and there was no evidence of AVG or Perkinsosis in any of the 42 abalone.

Some abalone showed signs of abscesses in pedal tissue consistent with bacterial infection (3 of 4 from Beachport and two of 11 from Port Macdonnell). Bacterial culture isolated Vibrio harveyi from a pedal vesicle of one abalone but no pathogenic bacterium was able to be isolated from the vesicles of the remaining four abalone.

\section{DISCUSSION}

A prolonged and extensive marine heatwave (SST $5^{\circ} \mathrm{C}$ greater than the historical average) occurred in South Australian waters between January and May 2013, peaking in March and April. This was associated with a widespread fish kill event across a similar geographic area as well as harmful algae blooms. Other observations included large amounts of dead seagrass/macroalgae and species observed outside their normal range (e.g., marine turtle species). The marine heatwave also coincided with unusually high dolphin mortalities which were associated with an outbreak of morbillivirus, with higher than normal water temperatures possibly playing a role (Kemper et al., 2016).

During the fish kill investigation, the majority of affected fish species reported were temperate shallow water benthic species generally with high site fidelity, such as reef species. Degens leatherjackets were the most numerous fish reported during the fish kill, likely due to their small size (linked to thermal tolerance and small gill surface area) and substantial population abundance (627 fish $\mathrm{ha}^{-1}$ ) in South Australian gulf waters (Figure 10; Currie et al., 2011). From dive surveys conducted during this investigation, it was established that only a small proportion of the fish populations died with underwater video footage showing large numbers of healthy fish in the murky green coastal water. Very few fish were observed to be unhealthy with signs of listing, spinning and poor swimming. Moribund and dead fish were observed to have bleeding gills, which is consistent with gill damage from harmful abrasive algae (Brusle, 1995; Rodger et al., 2010).

Generally, primary productivity and phytoplankton growth in Spencer Gulf and Gulf St Vincent is low, and is predominately limited by macronutrient concentrations (van Ruth, 2010, 2012; van Ruth and Doubell, 2013). During this fish kill, nutrient concentrations were lower than monthly and long-term averages. It appears that $\mathrm{NO}_{x}, \mathrm{PO}_{4}$, and $\mathrm{SiO}_{2}$ levels may have been depleted by increased diatom production prior to the macronutrient concentration levels measured on 3 April 2013. However, phytoplankton biomass and abundance in early April appeared typical to those found in lower Gulf St Vincent during April (van Ruth, 2010, 2012). By 19 April, production shifted to other smaller phytoplankton species. This shift in species is likely due to a change in the nitrogen source. For example, as $\mathrm{NO}_{x}$ does not readily diffuse across membranes, larger algae species typically have a competitive advantage to assimilate and store (Stolte et al., 1994; Stolte and Riegman, 1995, 1996). In contrast, due to its molecular change, $\mathrm{NH}_{4}$ diffuses over biological membranes resulting in fast assimilation rates, but is not readily stored (Stolte et al., 1994; Stolte and Riegman, 1995). Uptake rates are thus the more important factor when competing for $\mathrm{NH}_{4}$ (Stolte et al., 1994; Stolte and Riegman, 1995, 1996). Smaller species with high 
surface area to volume ratios, tend to have high uptake rate and dominate when $\mathrm{NH}_{4}$ is the source of nitrogen.

Phytoplankton composition is also an important factor to consider. A range of harmful algae species have been reported to occur in South Australia's gulfs. These species are generally rare or at levels well below bloom concentrations $(<5,000$ cells $\mathrm{L}^{-1}$ ) (van Ruth et al., 2009; van Ruth, 2010, 2012). In the current investigation, most of the potentially harmful or toxic phytoplankton species identified were rare and at very low concentrations that were unlikely to cause a fish mortality event. One potential harmful algae genus, Chaetoceros spp. were identified at abundances of up to 20,000 cells $\mathrm{L}^{-1}$. Issues with Chaetoceros spp. are typically restricted to species with barbed setae (siliceous spines on the protective armor of the cell). The majority of Chaetoceros spp. observed in water samples did not possess barbed setae. One species (Chaetoceros cf. coarctatus) with siliceous barbed setae was identified in net samples and subsequently in full species counts from water samples collected near the fish kill. C. coarctatus was found in abundances of between 200 and 2,000 cells $\mathrm{L}^{-1}$. Significant fish-kills have been reported at concentrations of $\sim 5,000$ cells $\mathrm{L}^{-1}$ (Hallegraeff, 2002), and have been known to cause sub-lethal effects (gill damage and stress) and mortality in fish at abundances of 400 cells $\mathrm{L}^{-1}$ (Albright et al., 1993). C. coarctatus has been identified previously in Gulf St Vincent, but typically prefers warmer waters (Hasle and Syvertsen, 1997). Given the high water temperatures and increased primary production suggested to have occurred prior to 3 April sampling, Chaetoceros cf. coarctatus was likely present in higher abundances in the lead-up to the major mortality event than those measured. The barbed setae of Chaetoceros cf. coarctatus can become lodged in the gills of fish and cause abrasive gill damage, stress and leave fish susceptible to secondary bacterial infections even at low, but persistent, abundances (Albright et al., 1993; Leterme et al., 2014), as observed during this investigation. Harmful Chaetoceros spp. can cause an accumulation of mucus on epithelium of gill lamellae, which limits dissolved oxygen diffusion contributing to hypoxia (Albright et al., 1993). Alterations to the mucus layer can also compromise the immune system leading to inflammation and necrosis (Albright et al., 1993; Kent et al., 1995; Kudela et al., 2005). Consequently, chronic exposure of even sub-lethal concentrations of HABs can lead to mortalities in less healthy fish from vibriosis infection and bacterial kidney disease (Albright et al., 1993; Rodger et al., 2010). This was also observed during the fish kill investigation, and associated with terminal systemic bacterial infection.

During this fish kill investigation, over 100 fish were submitted to the laboratory for analysis. Only 25 were suitable for histopathology and microbiology analysis, while only eight fish were deemed appropriate for meaningful interpretation. These fish were received alive or had clearly died a few hours prior to necropsy. Gill hyperplasia was observed in a number of these fish. Gill hyperplasia is a frequent finding in diseased fish, and can occur in response to infection, non-infectious causes or various stressors including elevated water temperature, poor water quality, hypoxia, overcrowding and excess algal growth (Roberts and Powell, 2003; Saber, 2011). Focal lesions effected $\sim 10 \%$ of the gill structure, and were generally $2-3$ gill lamellae in width. This lesion size corresponds with the size of $C$. coarctatus cells (25-45 $\mu \mathrm{m}$ apical axis, $13-20 \mu \mathrm{m}$ transapical axis) (Hasle and Syvertsen, 1997; Lee and Lee, 2011). Gill epithelial cells appeared "saw-toothed" and "ragged," and may be due to mechanical irritation. There is also an apparent increase in mucous cells and an infiltration of eosinophilic granulocytes, a typical inflammatory response. Diatom-like fragments of similar size to $C$. coarctatus cells were observed among the gill filaments and gill lamellae of the cowfish. The observed gill damage and associated inflammatory response may be attributed to the diatom spicules (personal communication, Dr. Brian Jones, Ministry for Primary Industries, New Zealand).

Globally, extreme water temperatures and harmful algae blooms are a cause of fish kills (Brusle, 1995; Rodger et al., 2010; Pearce and Feng, 2013). Higher than normal temperatures (at the limit of a fish's physiological tolerance), experienced as large temperature fluctuations, can lead to gill epithelial cell hyperplasia and hypertrophy, bloody congestion with hemorrhage and increased mucus production (Saber, 2011). Harmful (abrasive) algae can elicit a similar pathology in addition to focal lesions (Brusle, 1995; Rodger et al., 2010). These changes were observed in fish during the South Australian 2013 fish kill. Gill pathology (lesions) can lead to impacts on respiration, blood electrolyte regulation, cardiovascular disturbance and burden on the immune system (Roberts and Powell, 2003; Powell et al., 2008). While these impacts were likely sub-lethal due to approximately $<10 \%$ of the gill structure affected by lesions, gill disease exerts a substantial metabolic cost that can compromise the immune system of fish. In these cases, fish with an already weakened immune system (e.g., age, parasite load, thermal tolerance limits) may succumb to lethal bacterial infection. Histopathology demonstrated bacterial hyperplastic branchitis and septicaemia. The lesions caused by abrasive algal blooms in some cases likely resulted in terminal secondary bacterial infections in the few fish in the population that were likely immune-compromised. This was supported by the isolation of a Vibrio spp. or an unidentified Gram-negative bacterium in six of these eight fish. This resulted in a necrotic and hyperplastic branchitis which facilitated entry of bacteria with septicaemia, evidenced by widespread multi-organ bacterial emboli, and subsequent death. Various algal genera, including Chaetoceros spp., Skeletonema spp., Thalassiosira spp., Corethron spp. and others have been shown to cause gill hyperplasia, necrosis and increase mucus production (Kent et al., 1995; Kudela et al., 2005).

Abalone morbidity and mortality preceded the majority of fish mortalities. Abalone are susceptible to high water temperatures, which leads to immunosuppression and increases their susceptibility to secondary infections (commonly bacterial) (Bansemer et al., 2016). High water temperatures are a common factor in abalone kills (Vilchis et al., 2005). Gilroy and Edwards (1998) reported the 50\% critical thermal maxima for blacklip and greenlip abalone to be 26.9 and $27.5^{\circ} \mathrm{C}$, respectively. Further, Duong et al. (2016) reported a $60 \%$ mortality rate in greenlip abalone at $25^{\circ} \mathrm{C}$ in a laboratory temperature challenge model. During the marine heatwave, SST peaked at $\sim 27-30^{\circ} \mathrm{C}$. 
Unusually high water temperature was likely the primary cause of the abalone morbidity and mortality in this investigation, while periods of hypoxic conditions suggested from dive observations may have also been a contributing factor (Tripp-Valdez et al., 2017; Calderón-Liévanos et al., 2019). Similarly, an abalone mortality event was observed in Victoria at the same time as South Australia. Victorian investigators also attributed abalone mortalities to the warm water event (Victoria Department of Primary Industries, Personal communication). With regard to the histopathology, pedal lesions consistent with bacterial abscessation or cyst formation were observed in 10 of the 42 abalone (24\%) examined. Bacterial abscessation or cyst formation would have impacted mobility and feeding, and in abalone with multiple abscesses the infection would have likely caused toxemia and have been the cause of mortality. Vibrio infection in abalone has been shown to occur in abalone that are stressed with stressors including, amongst others, poor water quality, hypoxia, increased temperature, water fouling (Kua et al., 2011).

As outlined above, during this investigation over 100 fish were submitted to the laboratory, but only eight fish were deemed appropriate for analysis and meaningful interpretation (alive or recent dead). Numerous samples $(>90 \%)$ that arrived to the laboratory were not appropriate for diagnostic analysis and interpretation. This is a universally common issue for fish kill investigations (La and Cooke, 2011), where a large amount of time (i.e., days) can occur between mortality and sampling, including the time it takes for fish to wash ashore, the time until being observed and reported, and finally collected by fish kill investigators. This often results in inconclusive or inadequate evidence during fish kill investigations to identify a cause. For example, gill samples for histopathology ideally need to be collected and appropriately fixed within minutes of death to reduce post-mortem artifacts (Strzyzewska et al., 2016), while post-mortem microbial colonization occurs within hours. Similar issues, including deterioration, decomposition or contamination, are also encountered as a result of incorrect water sampling. While fish kill training for regional personnel (e.g., government, community groups, commercial fishers) and access to well-equipped fish kill kits can greatly assist investigations (Nowak et al., 2005; Roberts et al., 2013), knowledge from historical investigations (use of databases) and using a multidisciplinary approach assists with determining causes of fish kills (La and Cooke, 2011).

In conclusion, from available evidence the large scale 2013 fish kill event in South Australia was attributed to an extensive marine heatwave which promoted algae blooms, including the harmful diatom C. coarctatus. This resulted in physical gill damage and prolonged physiological stress leading to lethal bacterial septicaemia in a small proportion of the fish population. Of interest, abalone mortality occurred several weeks prior to the widespread fish kill event, suggesting they may be good bio-indicators of climate change, including impending impacts of marine heatwaves. This large scale fish kill event highlights the future effects of climate change on temperate marine ecosystems, fisheries and aquaculture, which are increasingly being documented (Weatherdon et al., 2016; Hobday et al., 2018). Since 1950, the average surface water temperatures in Spencer Gulf have increased by $0.11^{\circ} \mathrm{C} /$ decade, and it is expected to increase by greater than $2^{\circ} \mathrm{C}$ by 2100 (Shepherd and Baker, 2014). Marine heatwaves are projected to increase in frequency, duration and spatial extent (Frölicher et al., 2018; Oliver et al., 2018). From 1925 to 2016, global average marine heatwave frequency and duration has increased by 34 and $17 \%$, respectively (Oliver et al., 2018). This investigation demonstrated that most at risk will be temperate species in shallow water habitats already at their upper thermal tolerance limits, particularly those with high site fidelity.

Future research could seek to determine the effect of high temperature and HABs, including C. coarctatus, on key temperate species under controlled laboratory conditions to document cause and effect to further support this fish kill investigation. Importantly, trigger values for sub-lethal and lethal concentrations of $C$. coarctatus would provide valuable information for fish kill investigators in the future as well as aquaculture management. Finally, this information would be important for future climate proofing strategies, including risk and impact assessments underpinning the management of marine resources, fisheries, aquaculture and ecotourism (Weatherdon et al., 2016; Hobday et al., 2018). For example lethal and sub-lethal effects (e.g., thermal tolerance ranges) on various temperate marine species in response to climate change scenarios (including marine heatwaves) would greatly assist fisheries management (e.g., predict or help explain effects on recruitment) and aquaculture management (optimum species and locations for culture).

\section{DATA AVAILABILITY STATEMENT}

The datasets generated for this study are available on request to the corresponding author.

\section{ETHICS STATEMENT}

Ethical review and approval was not required for the animal study because all state animal welfare policies and legislations were adhered to.

\section{AUTHOR CONTRIBUTIONS}

SR led the investigation into the cause of the fish and abalone mortalities, and wrote the first draft of the manuscript. PV undertook nutrient sampling and analyses, and pigment and phytoplankton analyses. SR and PV wrote the remote sensing section. CW performed the phytoplankton analysis, SB provided histology, SB and SR provided interpretation of histopathology. All authors provided input into the drafting and review of the manuscript prior to submission. 


\section{FUNDING}

This research was supported by the State Government of South Australia: Primary Industries and Regions SA (PIRSA). Assistance was provided from other government agencies and volunteers.

\section{ACKNOWLEDGMENTS}

We would like to acknowledge staff involved in the fish kill investigation taskforce including: Scott Ashby (Chief Executive PIRSA, Chair of the taskforce), Will Zacharin, Prof. Mehdi Doroudi, Sean Sloan, Dr. Rob Rahaley, Vic Neverauskas, Alex Chalupa, John Gilliland, Peter Dietman, Randel Donovan, Andrew Carr, Prof. Gavin Begg, Dr. Marty Deveney, Dr. Stephen Mayfield, Prof. John Middleton and numerous other staff (in particular regional based staff) and colleagues who helped make this investigation successful. We would also like

\section{REFERENCES}

AG-DAFF, (2007). National Investigation and Reporting Protocol for Fish Kills. Canberra: Australian Government Department of Agriculture, Fisheries and Forestry.

Albright, L. J., Yang, C. Z., and Johnson, S. (1993). Sub-lethal concentrations of the harmful diatoms, Chaetoceros concavicornis and C. Convolutes, increase mortality rates of penned Pacific salmon. Aquaculture 117, 215-225. doi: 10. 1016/0044-8486(93)90321-o

Bansemer, M. S., Qin, J. G., Harris, J. O., Howarth, G. S., and Stone, D. A. J. (2016). Nutritional requirements and use of macroalgae as ingredients in abalone feed. Rev. Aquacult. 8, 121-135. doi: 10.1111/raq.12085

Brusle, J. (1995). The Impact of Harmful Algal Blooms on Fish - Mortality, Pathology and Toxicology. Brest: IFREMER.

Calderón-Liévanos, S., Hernández-Saavedra, N. Y., Lluch-Cota, S. E., CruzHernández, P., Ascencio-Valle, F. D. J., and Sicard, M. T. (2019). Survival and respiration of green abalone (Haliotis fulgens) facing very short-term marine environmental extremes. Mar. Freshw. Behav. Physiol. 52, 1-15. doi: 10.1080/ 10236244.2019.1607734

Currie, D. R., Dixon, C. D., Roberts, S. D., Hooper, G. E., Sorokin, S. J., and Ward, T. M. (2011). Relative importance of environmental gradients and historical trawling effort in determining the composition and distribution of benthic macro-biota in a large inverse estuary. Fish. Res. 107, 184-195. doi: 10.1016/ j.fishres.2010.11.003

Duong, D. N., Qin, J. G., Harris, J. O., Hoang, T. H., Bansemer, M. S., Currie, K.-L., et al. (2016). Effects of dietary grape seed extract, green tea extract, peanut extract and vitamin $C$ supplementation on metabolism and survival of greenlip abalone (Haliotis laevigata Donovan) cultured at high temperatures. Aquaculture 464, 364-373. doi: 10.1016/j.aquaculture.2016.07.011

Edyvane, K., and Shepherd, S. (1999). "South Australia," in Under Southern Seas: the Ecology of Australia's Rocky Reefs, ed. N. Andrew (Randwick, NSW: UNSW Press), 40-49.

Frölicher, T. L., Fischer, E. M., and Gruber, N. (2018). Marine heatwaves under global warming. Nature 560, 360-364. doi: 10.1038/s41586-018-0383-9

Gaughan, D. J., Mitchell, R. W., and Blight, S. J. (2000). Impact of mortality, possibly due to herpesvirus, on pilchard Sardinops sagax stocks along the south coast of Western Australia in 1998-99. Mar. Freshw. Res. 51, 601-612.

Gaut, A. C. (2001). Pilchard (Sardinops sagax) Mortality Events in Australia and Related World Events. Canberra: Fisheries Research and Development Corporation.

Gilroy, A., and Edwards, S. J. (1998). Optimum temperature for growth of Australian abalone: preferred temperature and critical thermal maximum for to thank Dr. Stephen Pyecroft (University of Adelaide), Dr. Brian Jones (Ministry for Primary Industries, New Zealand) and Dr. Fran Stephens (Department of Fisheries, Western Australia) for providing their comments and expert opinions on histopathology. And also thanks to South Australian commercial abalone fishers for reporting and submitting samples, Dr. Daren Hanshaw and staff from Gribbles Vetlab (Glenside); the Australian Animal Health Laboratories; Tim Kildea and Lorenzo Andreacchio (SA Water) for providing water samples and data; Dr. Ben Stobart, Andrew Hogg, Peter Hawthorne and the team (SARDI) for the collection of abalone; Dr. Gustaaf Hallegraeff of the University of Tasmania for confirming the identification of Chaetoceros coarctatus; Kaine Jakaitis for producing Figure 1; Mary-Anne Stacey from Outthereunderwater and Liz Ellinger and the team from the Pt Noarlunga Aquatic Centre for providing samples and observations. Special thanks to Ocean, Byron and Tamsin Roberts, and Karla Huffa for review and comments on the manuscript.

blacklip abalone, Haliotis rubra (Leach), and greenlip abalone, Haliotis laevigata (Leach). Aquac. Res. 29, 481-485. doi: 10.1046/j.1365-2109.1998.00241.x

Goggin, C. L., and Lester, R. J. G. (1995). Perkinsus, a protistan parasite of abalone in Australia: a review. J. Mar. Freshw. Res. 46, 639-646.

Hallegraeff, G. M. (2002). Aquaculturalists' Guide to Harmful Australian Microalgae. Hobart: University of Tasmania.

Harvell, C. D., Kim, K., Burkholder, J. M., Colwell, R. R., Epstein, P. R., Grimes, D. J., et al. (1999). Emerging marine diseases- climate links and anthropogenic factors. Science 285, 1505-1510. doi: 10.1126/science.285.5433.1505

Harvell, C. D., Mitchell, C. E., Ward, J. R., Altizer, S., Dobson, A. P., Ostfeld, R. S., et al. (2002). Climate warming and disease risks for terrestrial and marine biota. Science 296, 2158-2162. doi: 10.1126/science.1063699

Hasle, G. R., and Syvertsen, E. E. (1997). Marine Diatoms. in Identifying Marine Phytoplankton ed C. R. Tomas (San Diego, CA: Academic Press).

Hobday, A. J., Poloczanska, E. S., and Matear, R. J. (eds) (2008). Implications of Climate Change for Australian Fisheries, and Aquaculture: a Preliminary Assessment. Canberra: Department of Climate Change, Commonwealth of Australia.

Hobday, A. J., Spillman, C. M., Eveson, J. P., Hartog, J. R., Zhang, X., and Brodie, S. (2018). A framework for combining seasonal forecasts and climate projections to aid risk management for fisheries and aquaculture. Front. Mar. Sci. 5:137. doi: $10.3389 /$ fmars.2018.00137

Kemper, C. M., Tomo, I., Bingham, J., Bastianello, S. S., Wang, J., Gibbs, S. E., et al. (2016). Morbillivirus-associated unusual mortality event in South Australian bottlenose dolphins is largest reported for the South Hemisphere. R. Soc. Open Sci. 3:160838. doi: 10.1098/rsos.160838

Kent, M. L., Whyte, J. N. C., and LaTrace, C. (1995). Gill lesions and mortality in seawater pen-reared Atlantic salmon Salmo salar associated with a dense bloom of Skeletanema costatum and Thalassiosira species. Dis. Aquat. Org. 22, 77-81. doi: 10.3354/dao022077

Kim, D., and Oda, T. (2010). "Possible factors responsible for the fishkilling mechanisms of the red tide phytoplankton, Chattonella marina and Cochlodinium polykrikoides," in Coastal Environmental and Ecosystem Issues of the East China Sea, eds A. Ishimatsu, and H.-J. Lie (Tokyo: TERRAPUB and Nagasaki University), 245-268.

Kua, B. C., Ramli, R., Devakie, M. N., Groman, D., and Berthe, F. C. J. (2011). "Investigating a mortality in hatchery cultured tropical abalone, Haliotis asinina Linnaeus, 1758 in Malaysia," in Disease in Asian Aquaculture VII, eds M. G. Bondad-Reantaso, J. B. Jones, F. Corssin, and T. Aoki (Selangor: Fish Health Section, Asian Fisheries Society), 103-110.

Kudela, R., Pitcher, G., Figueiras, F., Moita, T., and Trainer, V. (2005). Harmful algal blooms in coastal upwelling systems. Oceanography 18, 185-197. 
La, V. T., and Cooke, S. J. (2011). Advancing the science and practice of fish kill investigations. Rev. Fish. Sci. 19, 21-33. doi: 10.1080/10641262.2010.531793

Lee, S. D., and Lee, J. H. (2011). Morphology and taxonomy of the planktonic diatom Chaetoceros species (Bacillariophyceae) with special intercalary setae in Korean coastal waters. Algae 26, 153-165. doi: 10.4490/algae.2011.26.2.153

Leterme, S. C., Jendyk, J.-G., Ellis, A. V., Brown, M. H., and Kildea, T. (2014). Annual phytoplankton dynamics in the Gulf Saint Vincent, South Australia, in 2011. Oceanologia 56, 757-778. doi: $10.5697 /$ oc. 56-4.757

Lugg, A. (2000). Fish kills in New South Wales. Orange, NSW: Department of Primary Industries.

Mayfield, S., Ferguson, G., Hogg, A., and Carroll, J. (2015). Southern Zone Abalone (Haliotis rubra and H. laevigata) Fishery. Fishery Assessment Report to PIRSA Fisheries and Aquaculture. SARDI Publication No. F2007/000552-5, SARDI Research Report Series No. 850. Adelaide: South Australian Reseach and Development Institute (Aquatic Sciences), 55.

McCarthy, B., Zukowski, S., Whiterod, N., Vilizzi, L., Beesley, L., and King, A. (2014). Hypoxic blackwater event severely impacts Murray crayfish (Euastacus armatus) populations in the Murray River, Australia. Austral. Ecol. 39, 491-500. doi: $10.1111 /$ aec. 12109

Middleton, J. F., and Bye, J. A. T. (2007). A review of the shelf slope circulation along Australia’s southern shelves: Cape Leeuwin to Portland. Prog. Oceanogr. 75, 1-41. doi: 10.1016/j.pocean.2007.07.001

Nowak, B., Crane, M., and Jones, B. (2005). Aquatic Animal Health Subprogram: Development of National Investigation and Reporting Protocols for Fish Kills in Recreational and Capture Fisheries. FRDC project 2005/620. Canberra: Fisheries Research and Development Corporation.

Nunes Vaz, R. A., Lennon, G. W., and Bowers, D. G. (1990). Physical behaviour of a large, negative or inverse estuary. Cont. Shelf Res. 10, 277-304. doi: 10.1016/ 0278-4343(90)90023-f

Oliver, E. C. J., Donat, M. G., Burrows, M. T., Moore, P. J., Smale, D. A., Alexader, L. V., et al. (2018). Longer and more frequent marine heatwaves over the past century. Nat. Commun. 9:1324. doi: 10.1038/s41467-018-03732-9

Pearce, A. F., and Feng, M. (2013). The rise and fall of the 'marine heat wave' off Western Australia during the summer of 2010/11. J. Mar. Syst. 112, 139-156. doi: 10.1016/j.jmarsys.2012.10.009

Pittock, B. (ed.) (2003). Climate. (change): An Australian Guide to the Science and Potential Impacts. Canberra: Australian Greenhouse Office.

Powell, M. D., Leef, M. J., Roberts, S. D., and Jones, M. A. (2008). Review: neoparamoebic gill infections: host response and physiology in salmonids. J. Fish Biol. 73, 2161-2183. doi: 10.1016/j.dci.2013.07.021

Roberts, S. D., Chalupa, A., Bombardieri, N., Kowalski, D., Deveney, M., Lauer, P., et al. (2013). Exercise Sea Fox: Testing Aquatic Animal Disease Emergency Response Capabilities Within Aquaculture, Adelaide, November. FRDC project 2012/044. Canberra: Fisheries Research and Development Corporation.

Roberts, S. D., Dixon, C. D., and Andreacchio, L. (2012). Temperature dependent larval duration and survival of the western king prawn, Penaeus (Melicertus) latisulcatus Kishinouye, from Spencer Gulf, South Australia. J. Exp. Mar. Biol. Ecol. 411, 14-22. doi: 10.1016/j.jembe.2011.10.022

Roberts, S. D., and Powell, M. D. (2003). Comparative ionic flux and gill mucous cell histochemistry: effects of salinity and disease status in Atlantic salmon (Salmo salar L.). Comp. Biochem. Physiol. 134, 525-537. doi: 10.1016/s10956433(02)00327-6

Roberts, S. D., Wilkinson, C., Stobart, B., Doubell, M., van Ruth, P., and Gilliland, J. (2014). Fish Kill Investigation: Coffin Bay harmful algal (Karenia mikimotoi) bloom February 2014. PIRSA Fisheries and Aquaculture Division Report. Adelaide: Primary Industries and Regions South Australia, 31.

Rodger, H. D., Henry, L., and Mitchell, S. O. (2010). Non-infectious gill disorders of marine salmonid fish. Rev. Fish Biol. Fish. 21, 423-440. doi: 10.1111/j.13652761.2011.01251.x

Rogers, P. J., Geddes, M., and Ward, T. M. (2003). Blue sprat Spratelloides robustus (Clupeidae: Dussumieriinae): a temperate clupeoid with a tropical life history strategy? Mar. Biol. 142, 809-824. doi: 10.1007/s00227-002-0973-8

Saber, T. H. (2011). Histological adaptation of thermal changes ion fills of common carp fishes Cyprinus carpio L. J. Raf. Sci. 22, 46-55.

Shepherd, S. A. (1984). Benthic communities of upper Spencer Gulf, South Australia. Trans. R. Soc. S. Aust. 107, 69-85.

Shepherd, S. A., and Baker, J. (2014). "Chapter 22: Reef fishes of spencer Gulf," in Natural History of Spencer Gulf, eds S. A. Shepherd, S. M. Madigan, B. M.
Gillanders, S. Murray-Jones, and D. J. Wiltshire (Adelaide: Royal Society of South Australia Inc), 444.

Stolte, W., McCollin, T., Noordeloos, A. A. M., and Riegman, R. (1994). Effect of nitrogen source on the size distribution within phytoplankton populations. J. Exp. Mar. Biol. Ecol. 184, 83-97. doi: 10.1016/0022-0981(94)90167-8

Stolte, W., and Riegman, R. (1995). Effect of phytoplankton cell size on transient state nitrate and ammonium uptake kinetics. Microbiology 141, 1221-1229. doi: 10.1099/13500872-141-5-1221

Stolte, W., and Riegman, R. (1996). A model approach for size-selective competition of marine phytoplankton for fluctuating nitrate and ammonium. J. Phycol. 32, 732-740. doi: 10.1111/j.0022-3646.1996.00732.x

Strzyzewska, E., Szarek, J., and Babinska, I. (2016). Morphologic evaluation of the gills as a tool in the diagnostics of pathological conditions in fish and pollution in the aquatic environment: a review. Vet. Med. 61, 123-132. doi: 10.17221/8763-vetmed

Tripp-Valdez, M. A., Bock, C., Lucassen, M., Lluch-Cota, S. E., Sicard, M. T., Lannig, G., et al. (2017). Metabolic response and thermal tolerance of green abalone juveniles (Haliotis fulgens: Gastropoda) under acute hypoxia and hypercapnia. J. Exp. Mar. Biol. Ecol. 497, 11-18. doi: 10.1016/j.cbpb.2018. 08.009

Van Heukelem, L., and Thomas, C. S. (2001). Computer-assisted high-performance liquid chromatography method development with applications to the isolation and analysis of phytoplankton pigments. J. Chromatogr. A 910, 31-49. doi: 10.1016/s0378-4347(00)00603-4

van Ruth, P., Thompson, P., Blackburn, S., and Bonham, P. (2009). “Temporal and spatial variability in phytoplankton abundance and community composition, and pelagic biogeochemistry in the tuna farming zone," in Aquafin CRC - Southern Bluefin Tuna Aquaculture Subprogram: Risk and Response Understanding the Tuna Farming Environment. Technical report, Aquafin CRC Project 4.6, FRDC Project 2005/059. SARDI Publication No F2008/0006461, SARDI Research Report Series No 344, eds J. E. Tanner, and J. Volkman (Adelaide: Aquafin CRC, Fisheries Research and Development Corporation and South Australian Research and Development Institute (Aquatic Sciences)), 287.

van Ruth, P. D. (2010). Adelaide Desalination Project Plankton Characterisation Study, Prepared for Adelaide Aqua. SARDI Publication. SARDI Publication No. F2010/000378-1. SARDI Research Report Series No. 487. Adelaide: South Australian Research and Development Institute (Aquatic Sciences), 39.

van Ruth, P. D. (2012). Adelaide Desalination Project Plankton Characterisation Study - Phase 2. Prepared for Adelaide Aqua. SARDI Publication No. F2010/000378-2. SARDI Research Report Series No. 606. Adelaide: South Australian Research and Development Institute (Aquatic Sciences), 40.

van Ruth, P. D., and Doubell, M. J. (2013). "Spatial and temporal variation in primary and secondary productivity and lower trophic ecosystem function in Spencer Gulf, South Australia," in PIRSA Initiative II: Carrying Capacity of Spencer Gulf: Hydrodynamic and Biogeochemical Measurement, Modelling and Performance Monitoring. FRDC Project No. 2009/046. SARDI Publication. SARDI Publication No. F2013/000311-1. SARDI Research Report Series No. 705, ed. J. F. Middleton (Adelaide: South Australian Research and Development Institute (Aquatic Sciences)), 97.

Vilchis, L. I., Tegner, M. J., Moore, J. D., Friedman, C. S., Riser, K. L., Robbins, T. T., et al. (2005). Ocean warming effects on growth, reproduction and survivorship of southern California abalone. Ecol. Appl. 15, 469-480. doi: 10.1890/03-5326

Weatherdon, L. V., Magnan, A. K., Roger, A. D., Sumaila, U. R., and Cheung, W. W. L. (2016). Observed and projected impacts of climate change on marine fisheries, aquaculture, coastal tourism and human health: an update. Front. Mar. Sci. 3:48. doi: 10.3389/fmars.2016.00048

Conflict of Interest: The authors declare that the research was conducted in the absence of any commercial or financial relationships that could be construed as a potential conflict of interest.

Copyright $\odot 2019$ Roberts, Van Ruth, Wilkinson, Bastianello and Bansemer. This is an open-access article distributed under the terms of the Creative Commons Attribution License (CC BY). The use, distribution or reproduction in other forums is permitted, provided the original author(s) and the copyright owner(s) are credited and that the original publication in this journal is cited, in accordance with accepted academic practice. No use, distribution or reproduction is permitted which does not comply with these terms. 